\title{
The St. Lawrence polynya and the Bering shelf circulation: New observations and a model comparison
}

\author{
S. Danielson, ${ }^{1}$ K. Aagaard, ${ }^{2}$ T. Weingartner, ${ }^{1}$ S. Martin, ${ }^{3}$ P. Winsor, ${ }^{4}$ G. Gawarkiewicz, ${ }^{4}$ \\ and D. Quadfasel ${ }^{5}$ \\ Received 31 August 2005; revised 12 January 2006; accepted 19 May 2006; published 19 September 2006.
}

[1] Using 14 yearlong instrumented moorings deployed south of St. Lawrence Island, along with oceanographic drifters, we investigate the circulation over the central Bering shelf and the role of polynyas in forming and disseminating saline waters over the shelf. We focus also on evaluating the Gawarkiewicz and Chapman (1995) model of eddy production within coastal polynyas. Principal results include the following. (1) The northern central shelf near-surface waters exhibit westward flow, carrying low-salinity waters from the Alaskan coast in fall and early winter, with consequences for water mass formation and biological production. (2) Within the St. Lawrence polynya the freshening effect of winter advection is about half as large as the salting effect of surface brine flux resulting from freezing. (3) Brine production over the Bering shelf occurs primarily offshore, rather than within coastal polynyas, even though ice production per unit area is much larger within the polynyas. (4) We find little evidence for the geostrophic flow adjustment predicted by recent polynya models. (5) In contrast to the theoretical prediction that dense water from the polynya is carried offshore by eddies, we find negligible cross-shelf eddy density fluxes within and surrounding the polynya and very low levels of eddy energy that decreased from fall to winter, even though dense water accumulated within the polynya and large cross-shore density gradients developed. (6) It is possible that dense polynya water was advected downstream of our array before appreciable eddy fluxes materialized.

Citation: Danielson, S., K. Aagaard, T. Weingartner, S. Martin, P. Winsor, G. Gawarkiewicz, and D. Quadfasel (2006), The St. Lawrence polynya and the Bering shelf circulation: New observations and a model comparison, J. Geophys. Res., 111, C09023, doi:10.1029/2005JC003268.

\section{Introduction}

[2] The northward flow of Pacific waters across the vast, shallow Bering Sea shelf is marked by a pronounced annual cycle in temperature and salinity. By late winter the water over the northern shelf is near freezing, and the salinity exceeds summer-fall values by 1-2 psu [Woodgate et al., 2005a]. These winter-modified Pacific waters subsequently enter the Arctic Ocean, and their enhanced salinity is critical to their location and influence within the Arctic Ocean [Aagaard et al., 1981]. A long-standing issue is the importance of freezing within coastal polynyas in seasonally elevating the salinity over the Bering shelf (compare Aagaard et al. [1981] and Schumacher et al. [1983] for

\footnotetext{
${ }^{1}$ Institute of Marine Science, University of Alaska, Fairbanks, Fairbanks, Alaska, USA.

${ }^{2}$ Applied Physics Laboratory, University of Washington, Seattle, Washington, USA.

${ }^{3}$ School of Oceanography, University of Washington, Seattle, Washington, USA. USA.

${ }^{4}$ Woods Hole Oceanographic Institution, Woods Hole, Massachusetts,

${ }^{5}$ Institut für Meereskunde, Universität Hamburg, Hamburg, Germany.

Copyright 2006 by the American Geophysical Union. 0148-0227/06/2005JC003268\$09.00
}

early discussions and Winsor and Björk [2000] for a recent modeling study).

[3] We here report measurements from moored instruments recording between September 1998 and September 1999 in the vicinity of the St. Lawrence Island polynya in the northern Bering Sea. Our objective was to observe the effects of this prominent polynya on the ocean and to compare our observations with the Gawarkiewicz and Chapman [1995] model of polynya-driven shelf circulation. A parallel paper by Drucker et al. [2003] discusses ice formation and redistribution within the St. Lawrence polynya, in part using upward looking sonar and CTD measurements made from our oceanographic moorings. Danielson and Kowalik [2005] employ the velocity measurements to help describe the spatial and temporal distribution of tidal currents near St. Lawrence Island.

[4] Figure 1 shows St. Lawrence Island to sit astride northerly flow over the shelf, which is intensified from the island northward. In winter, under conditions of strong northerly winds, a large polynya forms south of St. Lawrence [Pease, 1987; Drucker et al., 2003]. This polynya, as depicted in Figure 2, can extend nearly the $150 \mathrm{~km}$ length of the island, and measures as much as $25 \mathrm{~km}$ in the offshore direction [Drucker et al., 2003]. Heavy winter ice concen- 


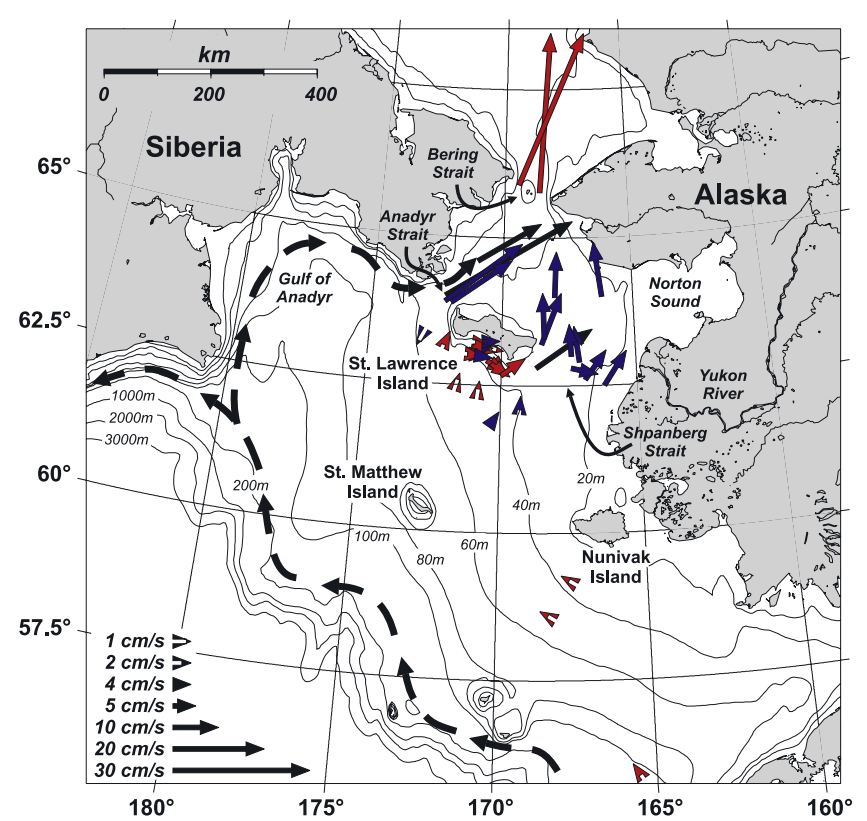

Figure 1. Place names, bathymetry, and circulation of the Bering Sea shelf. Vectors represent long-term moored current measurements and are either new measurements reported here or are adapted from Schumacher and Kinder [1983], Schumacher et al. [1983], Muench et al. [1988], Coachman [1993], and Roach et al. [1995]. Red vectors signify measurements within $10 \mathrm{~m}$ of the bottom and that extend over a full year; blue vectors are within $10 \mathrm{~m}$ of the bottom but miss the summer months; and black vectors are within $10 \mathrm{~m}$ of the bottom but during summer and fall only. The schematic portrayal of the Bering Slope Current and its northward offshoot around the Gulf of Anadyr (black dashed arrows) is adapted from Coachman [1993].

trations (about 0.8 in January and $0.9-1.0$ in February and March) are characteristic of much of the remaining northern shelf, and by midwinter the ice edge is about $200 \mathrm{~km}$ south of St. Lawrence, so that the seasonal ice edge is well removed from the polynya, as shown in Figure 3.

[5] At high latitudes the surface salt flux is particularly important in initiating ocean convection, because the thermal expansion coefficient for seawater is small near the freezing point, so that cooling generally represents a minor contribution to the total buoyancy flux. In turn, the surface salt flux is primarily induced by freezing (rather than by evaporation), with the majority of the salt in seawater being expelled during ice formation. Ice production and thus buoyancy forcing is enhanced in coastal polynyas, where offshore winds drive pack ice seaward, leaving open water where frazil ice production and brine rejection rates can be extremely high (compare Gill [1973] for a seminal discussion). For the 1998-1999 winter, surface heat flux calculations in the St. Lawrence polynya yield for wind-driven frazil ice polynyas, heat losses of $300-700 \mathrm{~W} \mathrm{~m}^{-2}$ and ice production rates of $0.1-0.2 \mathrm{~m} \mathrm{~d}^{-1}$ [Drucker et al., 2003], which implies salt rejection rates of $3-6 \mathrm{~kg} \mathrm{~m}^{-2} \mathrm{~d}^{-1}$. Furthermore, the surface buoyancy fluxes within this and other coastal polynyas are bounded on the seaward side by thick pack ice. As a consequence, a strong horizontal density gradient may be created near the offshore perimeter of the polynya and its newly formed dense water, giving rise to baroclinic pressure gradients with magnitudes comparable to rotational and frictional forces [Schumacher et al., 1983].

[6] Early work on the dispersion of dense water generated within coastal polynyas suggests that the modified waters spread via plumes and/or dense sheets within the benthic boundary layer [Gill, 1973; Killworth, 1973; Melling and Lewis, 1982; Aagaard et al., 1985b; Quadfasel et al., 1988; Melling, 1993; Schauer, 1995]. Geostrophy then dominates the dynamics, and the plume flows primarily along the isobaths. Downslope transport of the dense water is provided by a small ageostrophic component induced by bottom friction. Baines and Condie [1998] review work describing such dense plumes descending continental slopes, generally over a range of bottom slopes between $10^{-2}$ and $10^{-1}$.

[7] More recently, an alternate approach to buoyancydriven convection adjacent to coasts has been explored theoretically, based on time-dependent and three-dimensional nonlinear models [McDonald, 1993; Gawarkiewicz and

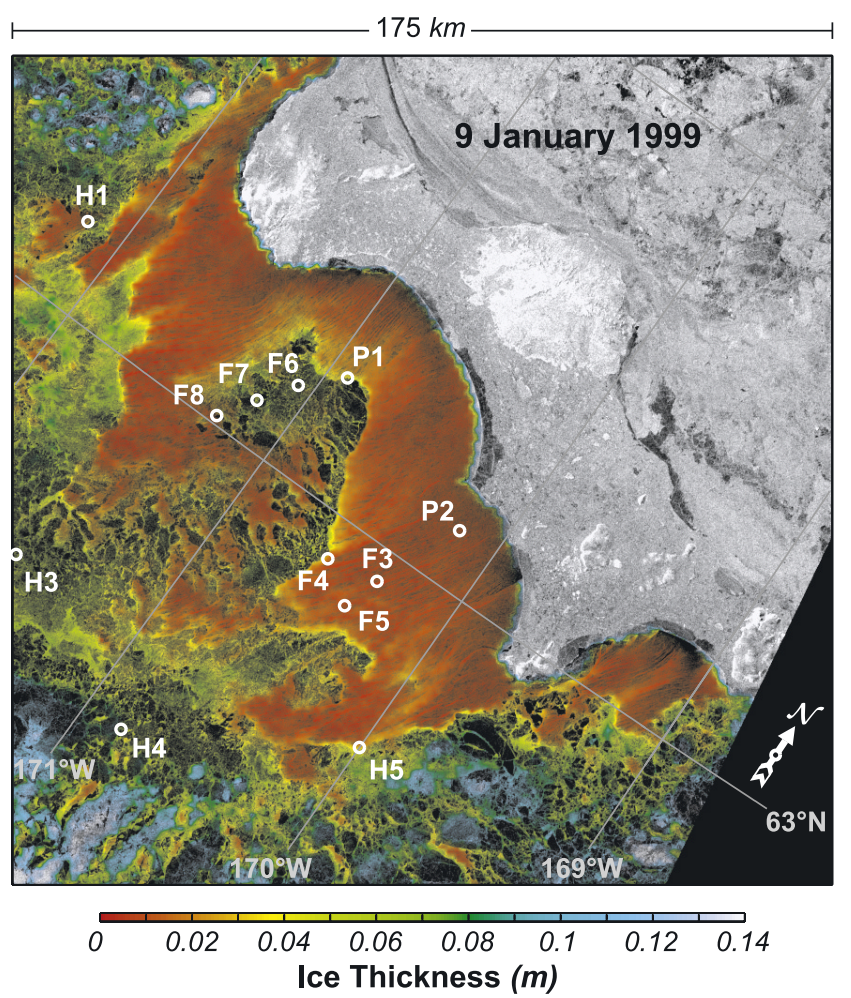

Figure 2. Composite synthetic aperture radar (SAR) and advanced very high resolution radiometer (AVHRR) image of the St. Lawrence Island polynya on 9 January 1999, adapted from Drucker et al. [2003]. The figure shows that the region within the polynya is strongly wind driven, with the winds and waves forcing the frazil ice into the long linear streaks characteristic of a Langmuir circulation. Mooring locations are plotted; Table 1 further describes the moorings and instrumentation. Moorings FTS6 and FTS8 were located $\sim 400 \mathrm{~m}$ and $\sim 300 \mathrm{~m}$ from $\mathrm{F} 6$ and F8, respectively. (SAR images copyright 1999 by the Canadian Space Agency.) 


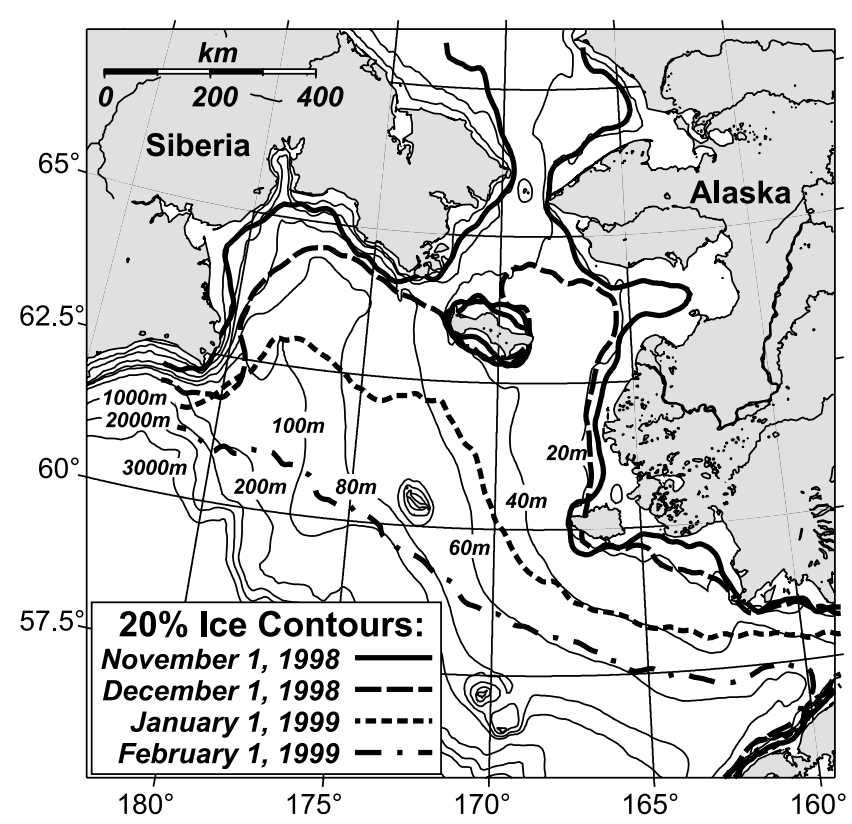

Figure 3. Contours depict the monthly ice edge location (20\% concentration) between 1 November 1998 and 1 February 1999, determined from the Special Sensor Microwave Imager (SSM/I) THIN2 ice algorithm of Cavalieri [1994].

Chapman, 1995; Chapman and Gawarkiewicz, 1995, 1997; Chapman, 1999, 2000; Gawarkiewicz, 2000]. For example, Gawarkiewicz and Chapman [1995] applied a constant negative buoyancy flux at the ocean surface over a semielliptical region adjacent to a straight coastline, simulating a coastal latent heat polynya on a shallow continental shelf with bottom slope of $\sim 10^{-3}$. At first the fluid remains within the forcing region and its density increases linearly with time, as does the strength of the front that forms along the offshore perimeter of the forcing region and the associated geostrophic flow. Eventually, baroclinically unstable waves develop along the front, and eddies detach from the forcing region and propagate across isobaths. These eddies transfer dense water offshore from the buoyancy-forced region and thus halt the growth of the density anomaly within the polynya.

[8] The St. Lawrence Island measurements reported here were part of a field program designed to specifically test the Chapmen-Gawarkiewicz models, e.g., whether a density front and associated geostrophic flow above a gently sloping bottom forms along the offshore edge of the polynya, eventually spawning instabilities; and whether observed density anomalies and other polynya features correspond to the theoretical scalings that have been proposed. If verified, the results would help both to parameterize sub grid processes in models and to apply remote sensing to ocean flux estimates. As usual, the measurements offered surprises.

[9] We chose to make our measurements on the south side of St. Lawrence Island, where the meteorological, ice, and oceanographic conditions are conducive to repeated latent heat polynya formation in winter [Schumacher et al., 1983; Pease, 1987; Smith et al., 1990; Drucker et al., 2003].
During winter, winds from the north and northeast prevail about $60 \%$ of the time, with characteristic speeds near $10 \mathrm{~m} \mathrm{~s}^{-1}$ and air temperatures typically of $-15^{\circ} \mathrm{C}$ to $-20^{\circ} \mathrm{C}$ [Drucker et al., 2003; Brower et al., 1988]. For the active polynya period of 1999 , atmospheric conditions largely conformed to this climatology. In an earlier study, Schumacher et al. [1983] found that such northerly wind events generally resulted not only in saline water produced south of the island, but also in reversal of the normally eastward flow, which they attributed to reversal of the pressure gradient that balances the geostrophic current.

[10] Section 2 of this paper describes our data and analytical methods. Section 3 first addresses the larger oceanographic setting and circulation on the Bering shelf, and then describes seasonal variability within the polynya, the oceanic response to polynya development and decay, and finally the winter salt balance. In section 4 , we consider the implications of our work for modeling studies, the contributions of the polynya to the regional salt and heat budgets, and the significance and representativeness of the St. Lawrence polynya.

\section{Data}

[11] Our study uses three distinct sets of measurements. Section 2.1 describes our moored observations, section 2.2 the drifter observations, and section 2.3 the satellite and meteorological data sets.

\subsection{Moored Measurements}

[12] We deployed fifteen moorings in September 1998 at the positions shown in Table 1 and Figure 2. Two of the moorings were designed to sample the polynya (P1 and P2), eight the frontal region along the offshore edge of the polynya (F3-F8), and five the ambient far field (H1-H5). Fourteen moorings were recovered the following September, but we could find no trace of mooring $\mathrm{H} 2$, which had likely been dragged away by ice. The moorings carried a combination of current meters (Aanderaa mechanical meters and $300 \mathrm{KHz}$ RDI Doppler profilers) and Sea-Bird temperature-conductivity recorders. The compass in the current meter on F7 failed, but all other instruments provided good records. Moorings FTS6 and FTS8, deployed to measure temperature and conductivity, were located approximately $300 \mathrm{~m}$ and $400 \mathrm{~m}$ from ADCP moorings F6 and F8 respectively.

[13] Calibration and processing procedures varied slightly between the three responsible institutes (at the Universities of Alaska, Hamburg, and Washington), but in general the various instruments were either calibrated by the manufacturer or at one of the institutes, most commonly both preand postdeployment, in which case the calibrations for the Sea-Bird instruments were linearly interpolated through time. The usual time checks, detrending, despiking, and manual editing routines were variously applied. A particular effort was devoted to the temperature records, where we strove for an especially accurate depiction of departures from the freezing point. For this purpose Sea-Bird exercised substantial additional calibration procedures, using instruments from moorings P1 and F4 as test subjects. The net result is that we believe the uncertainty in a single Sea-Bird temperature measurement is about $0.003^{\circ} \mathrm{C}$, close to the 
Table 1. Details of the Mooring Deployment Locations and Configurations ${ }^{\mathrm{a}}$

\begin{tabular}{|c|c|c|c|c|c|}
\hline Mooring Name & Latitude, ${ }^{\circ} \mathrm{N}$ & Longitude, ${ }^{\circ} \mathrm{W}$ & $\begin{array}{l}\text { Bottom } \\
\text { Depth, m }\end{array}$ & $\begin{array}{l}\text { Current Meter Type and } \\
\text { Instrument Depth, m }\end{array}$ & $\begin{array}{c}\mathrm{T} / \mathrm{C} \text { Recorder } \\
\text { Instrument Depth, } \mathrm{m}\end{array}$ \\
\hline P1 & $63^{\circ} 12.98^{\prime}$ & $170^{\circ} 55.16^{\prime}$ & 33 & RCM, 29 & 30 \\
\hline P2 & $63^{\circ} 6.35^{\prime}$ & $170^{\circ} 10.52^{\prime}$ & 33 & RCM, 28 & 29 \\
\hline F3 & $62^{\circ} 56.37^{\prime}$ & $170^{\circ} 19.96^{\prime}$ & 44 & $\mathrm{RCM}, 40$ & 41 \\
\hline F4 & $62^{\circ} 55.24^{\prime}$ & $170^{\circ} 33.01^{\prime}$ & 44 & $\mathrm{RCM}, 40$ & 41 \\
\hline F5 & $62^{\circ} 52.04^{\prime}$ & $170^{\circ} 22.98^{\prime}$ & 45 & $\mathrm{RCM}, 41$ & 42 \\
\hline F6 & $63^{\circ} 9.05^{\prime}$ & $171^{\circ} 3.95^{\prime}$ & 44 & ADCP, 39 & NI \\
\hline FTS6 & $63^{\circ} 9.14^{\prime}$ & $171^{\circ} 3.51^{\prime}$ & 43 & NI & 28 and 39 \\
\hline F7 & $63^{\circ} 4.98^{\prime}$ & $171^{\circ} 10.06^{\prime}$ & 48 & $\mathrm{CF}$ & 45 \\
\hline F8 & $63^{\circ} 1.03^{\prime}$ & $171^{\circ} 15.59^{\prime}$ & 50 & ADCP, 45 & NI \\
\hline FTS8 & $63^{\circ} 0.93^{\prime}$ & $171^{\circ} 15.84^{\prime}$ & 50 & RCM, 45 & 24 and 46 \\
\hline $\mathrm{H} 1$ & $63^{\circ} 9.73^{\prime}$ & $172^{\circ} 10.05^{\prime}$ & 60 & $\mathrm{RCM}, 22$ and 55 & 57 \\
\hline $\mathrm{H} 2$ & $62^{\circ} 50.02^{\prime}$ & $172^{\circ} 14.95^{\prime}$ & 55 & ML & ML \\
\hline $\mathrm{H} 3$ & $62^{\circ} 35.08^{\prime}$ & $171^{\circ} 35.15^{\prime}$ & 48 & $\mathrm{RCM}, 20$ and 43 & 45 \\
\hline $\mathrm{H} 4$ & $62^{\circ} 26.24^{\prime}$ & $170^{\circ} 49.69^{\prime}$ & 42 & RCM, 24 and 37 & 39 \\
\hline H5 & $62^{\circ} 40.04^{\prime}$ & $170^{\circ} 0.05^{\prime}$ & 42 & $\mathrm{RCM}, 24$ and 37 & 39 \\
\hline
\end{tabular}

${ }^{a}$ Figure 2 shows the mooring locations. All instruments recorded hourly time series spanning 14 September 1998 to 13 September 1999 . Abbreviations are as follows: RCM, mechanical recording current meter; ADCP, upward looking acoustic Doppler current profiler; NI, no instrument of this type deployed on this mooring; CF, mooring F7 compass failed; ML, mooring H2 was lost, probably carried off by ice.

limits imposed by the instruments within their calibration bath.

[14] Moorings FTS6 and FTS8 each carried two temperature-salinity recorders, separated vertically by 11 and $22 \mathrm{~m}$ respectively. Both sensor pairs showed periods (up to 1 month long) of apparent static instability, with density inversions typically $<0.1 \mathrm{~kg} \mathrm{~m}^{-3}$, but on two occasions (at FTS6 in April and August) reaching $0.5 \mathrm{~kg} \mathrm{~m}^{-3}$. We believe that these prolonged inversions represent transient fouling of a conductivity cell, possibly by drifting organisms impinging on the cell. Such fouling characteristically results in reduced conductivity. Winter inversions are evident when plotting the events in $T-S$ space, since the erroneous data falls below the freezing point curve during the inversion and then returns to slightly above the freezing point after the event. In other seasons, it is difficult to determine which of the sensor pairs is in error. We have not incorporated data during periods in which the density inversion exceeded $0.1 \mathrm{~kg} \mathrm{~m}^{-3}$. During periods when the inversion was between 0 and $0.1 \mathrm{~kg} \mathrm{~m}^{-3}$, we have taken the average of the two salinity values. The magnitude and duration of the inversions are such as to alter the reported seasonal mean salinities from their measured values at FTS6 by less than $0.07,0.06$ and 0.14 in fall, winter and summer respectively and at FTS 8 by less than $0.03,0.04$ and 0.01 during the same time periods.

[15] The principal instrumental problem proved to be suspiciously low current speeds that occurred over limited periods at several locations. We therefore calculated the characteristics for the two largest tidal constituents $\mathrm{M}_{2}$ and $\mathrm{K}_{1}$ in all the current records (including the Doppler measurements), both for the year and for consecutive 29 day periods, looking for anomalous behavior. We found consistent low-speed anomalies in three instances, totaling eight instrument months, viz., at P1 during early February to early March, at H1 (22 m) during mid-August to mid-September, and at FTS8 during November to April. Given the timing of the anomalies, the problem cannot be solely assigned to rotor freezing. Other possibilities include rotor fouling by drifting organisms, e.g., medusae. In any event, we have not used the eight instrument months of suspect records in our calculations.

\subsection{Drifter Measurements}

[16] Between 13 and 22 September 2002, fifteen Technocean ARGOS-tracked drifting buoys were deployed near Nunivak Island (http://www.ims.uaf.edu/NPRBdrifters/). Two of the drifters did not yield usable data: one grounded shortly after deployment and one never achieved reliable satellite communications. The grounded drifter gives us opportunity to examine the accuracy of the position fixes and speed estimates. If position errors are random, then the mean position error is $<20 \mathrm{~m}$ with a standard deviation of $\sim 15 \mathrm{~m}$. Hence hourly speed estimates have an uncertainty of $<1 \mathrm{~cm} \mathrm{~s}^{-1}$. Eight of the surviving drifters were of the SVP (Surface Velocity Program) holey-sock type, drogued at $10 \mathrm{~m}$, while the remainder were CODE (Coastal Ocean Dynamics Experiment) cross-shaped Davis drifters with the sail set at $1 \mathrm{~m}$ depth. The SVP drifters were variously tracked until late December to mid-February, while the CODE drifters functioned until mid-November to midDecember.

[17] Taken as a whole, the drifter tracks shown in Figure 4 indicate a systematic trajectory pattern until about mid November, when they were broadly distributed to the south of St. Lawrence Island. The ice edge progressed over the northeastern shelf from $64^{\circ} \mathrm{N}$ to $60^{\circ} \mathrm{N}$ between about 25 December 2002 and 7 January 2003. One drifter followed the ice edge south and wound up near St. Matthew Island by the end of January. A zigzag path was followed by the entire set of usable drifters between 12 and 22 October 2002. This period provides us opportunity to examine potential differences in drifter response to the wind before the drifters were greatly separated. During these 11 days, strong winds (mean magnitude $>10 \mathrm{~m} \mathrm{~s}^{-1}$ ) shifted from southeasterlies to northeasterlies, resulting in a total transit of $\sim 200 \mathrm{~km}$ and a net displacement of $\sim 100 \mathrm{~km}$ due west. Regression analysis comparing velocities from the two drifter types shows that, at the $95 \%$ confidence level, their motions are indistinguishable over this time period.

[18] We have therefore utilized both the CODE- and SVP-derived velocities in assembling an overview of the regional circulation (Figure 4 and Table 2). From the individual drift tracks we calculate mean hourly velocities of all drifters collocated within grid cells sized $1^{\circ}$ 


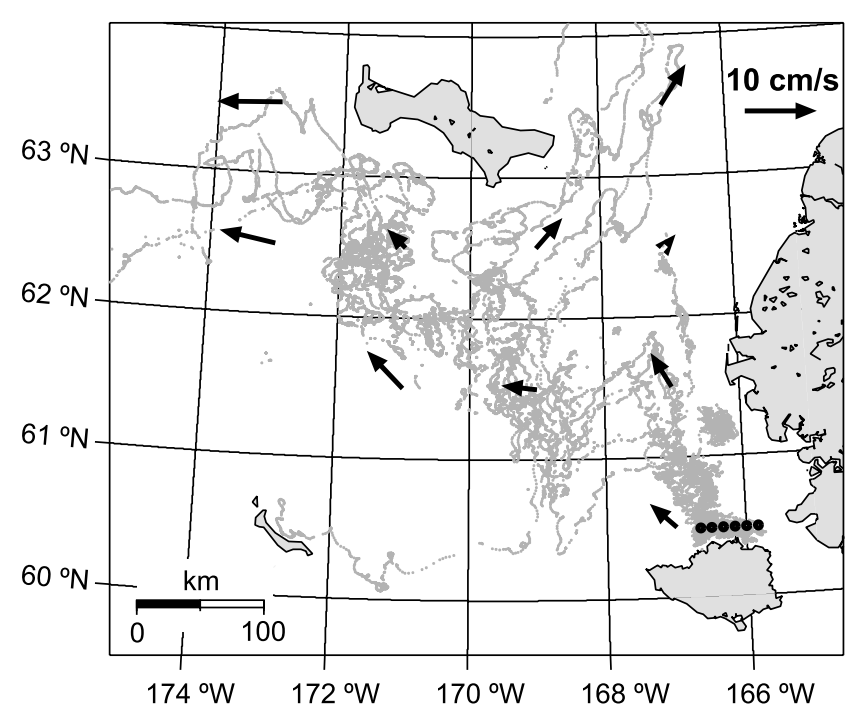

Figure 4. Locations of good GPS position fixes during the drifter deployment (gray dots). The velocity vectors are calculated as averages within boxes sized $1^{\circ}$ latitude $\times 2^{\circ}$ longitude, denoted by the grid lines. Each vector represents at least 2 weeks worth of hour-long velocity estimates; see Table 2 for details.

latitude $\times 2^{\circ}$ longitude. We then average all hourly means to create the single vector representing the grid cell, plotting vectors only in grids for which there is at least 336 hours ( 2 weeks) worth of data. Error analysis shows that none of the resultant vectors are significantly different than zero, so that Figure 4 merely provides a set of mostly consecutive snapshots rather than a robust seasonal mean. In part, the large error bars reflect the substantial tidally induced variance, which can account for more than $50 \%$ of the total [Danielson and Kowalik, 2005]. Filtering to remove the tidal motion increases the decorrelation timescale so the mean vectors are still not statistically different from zero at the $95 \%$ confidence level. Error bars not withstanding, these snapshots do afford us a glimpse at a mechanism that may be responsible for delivering coastal waters to the mid shelf region.

\subsection{Atmospheric and Satellite Data}

[19] The surface wind has been calculated from the ECMWF gridded pressure field, and we have chosen a center point in that grid $\left(63^{\circ} 22^{\prime} \mathrm{N}, 171^{\circ} 00^{\prime} \mathrm{W}\right)$ located near the northeast corner of St. Lawrence Island, as representa- tive of the regional wind field. As a compromise between times of ice cover and open water, we reduced the geostrophic wind by $25 \%$ and rotated it $15^{\circ} \mathrm{CCW}$ [Aagaard et al., 1989; Bond et al., 1994]. We note that our results are relatively insensitive to wind parameterizations. The air temperature has been interpolated as described by Drucker et al. [2003]. Finally, the location of the ice edge, in the form of the $20 \%$ total ice concentration, has been determined from the passive microwave satellite imagery using the Special Sensor Microwave Imager (SSM/I) THIN2 ice algorithm of Cavalieri [1994].

[20] Regarding the regional meteorology, in both Drucker et al. [2003] and the present paper, we ignore the island topography and calculate the heat flux and wind velocity from a single point. Figure 5 shows that the island topography is dominated by two sets of mountains, those immediately north of Southwest Cape $(500 \mathrm{~m})$, and the Kookooligit Mountains $(670 \mathrm{~m})$ in the north central part of the island. From his low-level aircraft experiments, Walter [1989] shows that for the Southwest Cape topography and northeast winds in particular, there is a zonal convergence downwind of the Cape, as well as a decrease in meridional wind speed and an increase in air temperature. He also found that because the Kookooligit Mountains are located further north of the polynya and has topography that slopes gently toward the beach, its effect on the aircraft observed winds and temperatures is much less than Southwest Cape, where the mountainous terrain is located immediately adjacent to the coast line. Walter [1989] concludes that modeling of the polynya behavior must take into account the effect of topography.

\section{Results}

[21] We present our results in four parts. Section 3.1 describes the general circulation over the Bering shelf, section 3.2 the seasonal variability of the circulation within the polynya region, section 3.3 the ocean response to the St. Lawrence polynya, and section 3.4 the winter salt balance.

\subsection{Circulation Over the Bering Shelf}

[22] The generally northward flow across the Bering shelf transfers water from the North Pacific to the Arctic Ocean (Figure 1). To the south, the Bering Slope Current runs parallel to the southern edge of the shelf, where probably near $180^{\circ}$ a portion of its transport is directed northward onto the western shelf [Coachman, 1993]. This flow carries saline and nutrient-rich water northward and eastward

Table 2. Summary of the Drifter-Derived Velocity Vectors and Associated Statistics ${ }^{\mathrm{a}}$

\begin{tabular}{ccccccc}
\hline Latitude, ${ }^{\circ} \mathrm{N}$ & Longitude, ${ }^{\circ} \mathrm{W}$ & Start Date & End Date & $N$, hours & Speed, cm $/ \mathrm{s}$ & Direction, ${ }^{\circ} \mathrm{T}$ \\
\hline 60.5 & 167 & 13 Sep 2002 & 19 Oct 2002 & 815 & 4.0 & 316 \\
61.5 & 171 & 25 Oct 2002 & 3 Dec 2002 & 491 & 6.3 & 319 \\
61.5 & 169 & 18 Oct 2002 & 5 Jan 2003 & 722 & 5.2 & 285 \\
61.5 & 167 & 27 Sep 2002 & 19 Oct 2002 & 489 & 5.4 & 323 \\
62.5 & 173 & 19 Nov 2002 & 13 Jan 2003 & 441 & 7.1 & 273 \\
62.5 & 171 & 6 Nov 2002 & 31 Dec 2002 & 1179 & 3.3 & 319 \\
62.5 & 169 & 21 Oct 2002 & 3 Jan 2003 & 962 & 5.6 & 44 \\
62.5 & 167 & 13 Oct 2002 & 2 Jan 2003 & 371 & 1.3 & 33 \\
63.5 & 173 & 19 Dec 2002 & 11 Jan 2003 & 385 & 9.1 & 269 \\
63.5 & 167 & 4 Dec 2002 & 1 Jan 2003 & 484 & 6.6 & 32 \\
\hline
\end{tabular}

${ }^{\mathrm{a}}$ Given are the grid cell center coordinates, the range of dates and number of samples comprising each vector, and the computed mean speed and direction. 


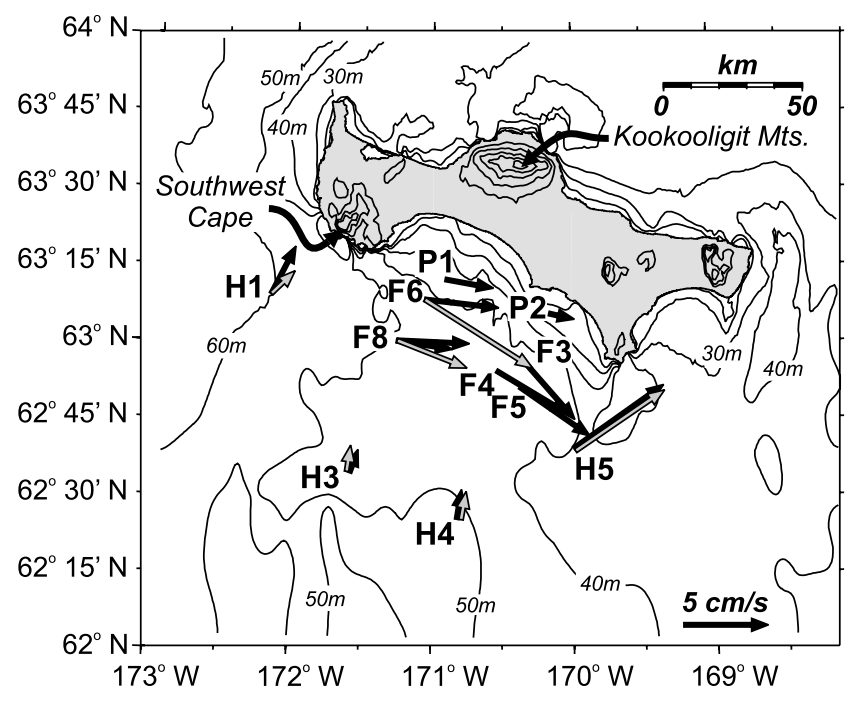

Figure 5. Study area near the St. Lawrence polynya, with record-length mean currents for the 1998-1999 deployment year. For moorings with two mechanical current meters (H1-H5), black arrows denote the lower instrument and gray arrows denote the upper. For moorings with acoustic Doppler current profilers (ADCPs) (F6 and F8), the arrows represent bins with heights above bottom comparable to those at the $\mathrm{H}$ moorings. The two black vectors plotted near label F8 are from moorings F8 and FTS8. Bathymetric contours are at $10 \mathrm{~m}$ intervals; topographic contours are at $100 \mathrm{~m}$ intervals.

around the Gulf of Anadyr and eventually through Bering Strait, while less saline waters move northward over the eastern shelf. The mean flow is weak over most of the southern shelf, with long-term averages of typically $2-3 \mathrm{~cm} \mathrm{~s}^{-1}$ [Schumacher and Kinder, 1983], but with stronger currents over the northern shelf [Coachman, 1993; Muench et al., 1988; Schumacher et al., 1983]. Through Anadyr Strait, northwest of St. Lawrence Island, the mean flow is probably about $20 \mathrm{~cm} \mathrm{~s}^{-1}$, while through Shpanberg Strait to the east, it is likely in the range 10$15 \mathrm{~cm} \mathrm{~s}^{-1}$ [Schumacher et al., 1983; Muench et al., 1988; Coachman, 1993].

[23] The northward flow over at least the northern portion of the shelf is considerably stronger in summer, under prevailing southerly winds, than it is during other seasons. This is true not only in Bering Strait [Aagaard et al., 1985a], but also on the shelf at least as far south as Anadyr and Shpanberg straits (contrast the black (summer and fall) and blue (no summer) vectors in Figure 1 [see also Coachman, 1993]), as is required to maintain mass continuity.

[24] These ideas and numbers are well established in the literature. New, however, is the evidence from our drifter measurements that over much of the northern shelf the nearsurface flow can be markedly westward or northwestward (hereafter referred to for simplicity as westward), with typical speeds of $5-10 \mathrm{~cm} \mathrm{~s}^{-1}$ during the fall and early winter months (Figure 4). While winds from the north or northeast prevailed during much of this time, the simultaneous current record from Bering Strait shows predominantly northerly flow except for two brief reversals (compare mooring A3 in Woodgate et al. [2005a, Figure 5]). Since the prevailing northward throughflow over the shelf and through Bering Strait is much as during other years, the observed westward motion over the central shelf would appear to be part of the normal circulation pattern.

[25] In contrast, Figure 5 shows the land and bottom topography and the mean flow for the entire record in our study region during 1998-1999. Immediately south of St. Lawrence Island, the flows are generally eastward or southeastward, with means of about $5 \mathrm{~cm} \mathrm{~s}^{-1}$ or less. This agrees with the suggestion of Coachman et al. [1975], based on hydrography, as well as with the earlier measurements of Schumacher et al. [1983] and Muench et al. [1988]. The eastward movement is restricted to a band extending offshore perhaps $60-70 \mathrm{~km}$, while south of this region the flow is northward, but weak $\left(<2 \mathrm{~cm} \mathrm{~s}^{-1}\right)$. Our moorings $\mathrm{H} 1-\mathrm{H} 4$, which we had placed to measure far-field conditions, thus represent a transitional regime, probably not exceeding $100 \mathrm{~km}$ in north-south extent, between the westward movement farther south over the central shelf and the eastward motion immediately south of St. Lawrence Island (Figures 4 and 5). In effect, this transitional regime feeds low-salinity waters northward into the region surrounding the polynya. Here these waters compete for control of the salinity field with saline waters carried eastward from the Gulf of Anadyr, and in winter with even more saline water produced by freezing in the polynya.

[26] What might sustain the westward motion over the central shelf? Almost surely, such regionally pervasive flow would show a geostrophic tendency, even if frictionally modified. Comparison with the dynamic topography [Ohtani, 1969], which shows an anticyclonic loop to be associated with the low-salinity tongue, rather than a broad westward flow, suggests that only over the southern portion of the central shelf is the baroclinic pressure field of the right sign to support a westward geostrophic flow. This in turn would require much of a westward geostrophic flow to be barotropic. We note that published models have not reproduced the westward flow, whether wind-driven, forced by a prescribed sea level slope (or transport through Bering Strait), or both [Kinder et al., 1986; Overland and Roach, 1987].

[27] We note also that the observed westward flow will transport low-salinity water from near the Alaskan coast westward across the shelf, and we suggest that this feature of the shelf circulation is critical to maintaining the water properties on the central shelf, the so-called Bering Shelf water (BSW) [Coachman et al., 1975]. In particular, the salinity and ${ }^{18} \mathrm{O}$ characteristics of the BSW suggest that it is a blend of saline and isotopically heavy waters from 50 to $200 \mathrm{~m}$ within the Bering Slope Current with isotopically light freshwater derived, most prevalently, from the Alaskan coast [Amos and Coachman, 1992; Coachman and Shigaev, 1992]. The westward transport portrayed in Figure 4 is thus the vehicle for bringing the Alaskan coastal waters onto a portion of the shelf where the mixing with saline waters to the west can occur (compare Coachman et al. [1975] for a related discussion).

[28] The overall salinity distribution on the Bering shelf [Coachman et al., 1975, Figure 13] is consistent with the circulation scheme outlined above. In particular, a broad tongue of low-salinity water extending westward across the 
Table 3. Temperature and Salinity Statistics at the Mooring Sites During the Three Seasonal Time Frames: 14 September-31 December 1998, 1 January-30 April 1999, and 1 May-13 September 1999

\begin{tabular}{|c|c|c|c|c|c|c|c|}
\hline \multirow[b]{2}{*}{ Mooring Name } & \multirow[b]{2}{*}{ Depth, m } & \multicolumn{3}{|c|}{ Temperature, ${ }^{\circ} \mathrm{C}$} & \multicolumn{3}{|c|}{ Salinity } \\
\hline & & Mean & Min. & Max. & Mean & Min. & Max. \\
\hline \multicolumn{8}{|c|}{14 Sep 1998 to 31 Dec 1998} \\
\hline P1 & 30 & 0.14 & -1.77 & 2.17 & 31.85 & 31.22 & 32.61 \\
\hline P2 & 29 & 0.25 & -1.79 & 3.98 & 31.76 & 31.24 & 32.46 \\
\hline F3 & 41 & 0.28 & -1.77 & 2.9 & 31.69 & 31 & 32.57 \\
\hline F4 & 41 & 0.35 & -1.76 & 3.27 & 31.68 & 31.17 & 32.56 \\
\hline F5 & 42 & 0.49 & -1.77 & 3.55 & 31.64 & 31.18 & 32.54 \\
\hline FTS6 & 28 & 0.76 & -1.76 & 4.68 & 31.65 & 30.53 & 33.06 \\
\hline FTS6 & 39 & -0.03 & -1.75 & 2.2 & 31.82 & 31.12 & 32.58 \\
\hline F7 & 45 & -0.06 & -1.74 & 2.45 & 31.85 & 31.2 & 32.49 \\
\hline FTS8 & 24 & 1.77 & -1.73 & 5.84 & 31.47 & 31.1 & 32.28 \\
\hline FTS8 & 46 & 0.04 & -1.73 & 2.49 & 31.71 & 31.1 & 32.45 \\
\hline $\mathrm{H} 1$ & 57 & 0.2 & -1.42 & 2.48 & 32.05 & 31.31 & 32.98 \\
\hline $\mathrm{H} 3$ & 45 & 1.05 & -1.73 & 3.75 & 31.53 & 31.21 & 31.94 \\
\hline $\mathrm{H} 4$ & 39 & 1.55 & -1.78 & 4.15 & 31.42 & 31.06 & 31.76 \\
\hline H5 & 39 & 1.18 & -1.75 & 3.96 & 31.48 & 31.14 & 32.35 \\
\hline \multicolumn{8}{|c|}{1 Jan 1999 to $30 \mathrm{Apr} 1999$} \\
\hline P1 & 30 & -1.8 & -1.87 & -0.91 & 32.98 & 32.18 & 34.03 \\
\hline P2 & 29 & -1.83 & -1.9 & -1.54 & 33.48 & 32.04 & 34.51 \\
\hline F3 & 41 & -1.8 & -1.87 & -1.02 & 33.06 & 31.97 & 33.95 \\
\hline F4 & 41 & -1.77 & -1.86 & -0.34 & 32.72 & 31.84 & 33.83 \\
\hline F5 & 42 & -1.78 & -1.87 & -0.75 & 32.8 & 31.77 & 33.96 \\
\hline FTS6 & 28 & -1.78 & -1.85 & -0.75 & 32.58 & 31.93 & 33.59 \\
\hline FTS6 & 39 & -1.77 & -1.86 & -0.46 & 32.72 & 32.02 & 33.8 \\
\hline F7 & 45 & -1.72 & -1.84 & 0.37 & 32.56 & 31.83 & 33.67 \\
\hline FTS8 & 24 & -1.76 & -1.84 & -1.43 & 32.32 & 31.72 & 33.48 \\
\hline FTS8 & 46 & -1.67 & -1.84 & 0.4 & 32.42 & 31.88 & 33.51 \\
\hline H1 & 57 & -1.75 & -1.83 & 0.44 & 32.53 & 32.01 & 33.2 \\
\hline $\mathrm{H} 3$ & 45 & -1.76 & -1.8 & -1.68 & 32.05 & 31.72 & 32.9 \\
\hline H4 & 39 & -1.75 & -1.8 & -1.68 & 31.94 & 31.53 & 32.91 \\
\hline H5 & 39 & -1.77 & -1.86 & -1.66 & 32.3 & 31.57 & 33.76 \\
\hline \multicolumn{8}{|c|}{1 May 1999 to 13 Sep 1999} \\
\hline P1 & 30 & -1.29 & -1.81 & 0.96 & 32.68 & 31.94 & 33.14 \\
\hline P2 & 29 & -0.25 & -1.83 & 5.86 & 32.5 & 31 & 33.09 \\
\hline F3 & 41 & -1.38 & -1.79 & -0.31 & 32.61 & 31.73 & 33.12 \\
\hline F4 & 41 & -1.5 & -1.77 & -0.96 & 32.55 & 31.79 & 33.1 \\
\hline F5 & 42 & -1.45 & -1.76 & -0.8 & 32.52 & 31.37 & 33.15 \\
\hline FTS6 & 28 & -1.44 & -1.81 & 6.59 & 32.5 & 31.45 & 33.1 \\
\hline FTS6 & 39 & -1.57 & -1.79 & -0.94 & 32.58 & 31.98 & 33.06 \\
\hline F7 & 45 & -1.62 & -1.79 & -1.36 & 32.34 & 31.72 & 32.9 \\
\hline FTS8 & 24 & -0.94 & -1.77 & 7.09 & 32.16 & 30.53 & 32.95 \\
\hline FTS8 & 46 & -1.63 & -1.78 & -1.34 & 32.32 & 31.61 & 32.97 \\
\hline H1 & 57 & -1.68 & -1.81 & -1.51 & 32.43 & 31.76 & 33.17 \\
\hline $\mathrm{H} 3$ & 45 & -1.55 & -1.75 & -1.07 & 31.86 & 31.32 & 32.63 \\
\hline $\mathrm{H} 4$ & 39 & -1.43 & -1.76 & -0.67 & 31.98 & 31.44 & 32.8 \\
\hline H5 & 39 & -1.41 & -1.79 & -0.58 & 32.18 & 31.49 & 32.78 \\
\hline
\end{tabular}

shelf north of $60^{\circ} \mathrm{N}$ is coincident with the midshelf westward flow indicated in Figure 4, although the details of the low-salinity tongue vary from year to year [Takenouti and Ohtani, 1974, Figure 2.9b]. Farther west lies water of high salinity (33 or more, even in summer), connected with the Bering Sea slope, which presumably is its immediate source. South of St. Lawrence Island, the isohalines are nearly aligned with the island, with saline water extending eastward from the Gulf of Anadyr to just east of St. Lawrence, where it presumably turns north, passing through Shpanberg Strait and subsequently through Bering Strait. This implied saline water trajectory coincides with the observed eastward motion at the $\mathrm{F}$ and $\mathrm{P}$ moorings (Figure 5) and the flow resultant from this eastbound saline water turning northward to pass east of St. Lawrence, observed both at mooring $\mathrm{H} 5$ and the drifter grid cell centered on $169^{\circ} \mathrm{W}, 62.5^{\circ} \mathrm{N}$.

\subsection{Seasonal Variability in the Polynya Region During 1998-1999}

[29] In general, we have divided the oceanographic and meteorological time series into three seasonal segments, representing fall, winter, and spring and summer. Table 3 summarizes the ocean temperature and salinity properties for each season; Table 4 summarizes the wind properties and the ocean velocity and kinetic energy properties. Figure 6 provides a schematic of the velocities and salinity properties for each season. In these, mid-September through December 1998 represents fall, with low salinities and relatively strong mean flow; January through April 1999 represents winter, with an active polynya, high salinities, and weak mean flow; and May through mid-September 1999 represents spring and summer, with a weak mean wind, intermediate salinities, and a mean flow that at most locations is reduced from that during fall. 
Table 4. Seasonal Wind and Velocity Statistics, the Latter Based on the Deepest Current Meter Records ${ }^{\mathrm{a}}$

\begin{tabular}{|c|c|c|c|c|c|c|c|c|}
\hline Data Set & $\begin{array}{l}\text { Net Speed, } \\
\mathrm{m} \mathrm{s}^{-1}, \mathrm{~cm} \mathrm{~s}^{-1}\end{array}$ & $\begin{array}{c}\text { Net } \\
\text { Dir., }{ }^{\circ} \mathrm{T}\end{array}$ & $\begin{array}{l}\text { Maximum Speed, } \\
\mathrm{m} \mathrm{s}^{-1}, \mathrm{~cm} \mathrm{~s}^{-1}\end{array}$ & $\begin{array}{c}\text { Dir. of Principal } \\
\text { Axis, }{ }^{\circ} \mathrm{T}\end{array}$ & $\begin{array}{c}\text { Principal } \\
\text { Axis Ratio }\end{array}$ & $\begin{array}{c}\text { MKE, } \mathrm{m}^{2} \mathrm{~s}^{-2} \\
\mathrm{~cm}^{2} \mathrm{~s}^{-2}\end{array}$ & $\begin{array}{c}\text { MEKE, } \mathrm{m}^{2} \mathrm{~s}^{-2}, \\
\mathrm{~cm}^{2} \mathrm{~s}^{-2}\end{array}$ & KE Ratio \\
\hline \multicolumn{9}{|c|}{14 Sep 1998 to 31 Dec 1998} \\
\hline ECMWF winds & 2.74 & 250 & 23.2 & 160 & 0.65 & 3.8 & 31.2 & 8.3 \\
\hline P1 & 3.56 & 108 & 41.4 & 111 & 0.29 & 6.4 & 43 & 6.8 \\
\hline P2 & 1.84 & 106 & 31.3 & 100 & 0.46 & 1.7 & 15.1 & 8.9 \\
\hline F3 & 6.75 & 128 & 52.2 & 127 & 0.28 & 22.8 & 95.3 & 4.2 \\
\hline F4 & 8.78 & 113 & 56.6 & 123 & 0.34 & 38.5 & 114.7 & 3 \\
\hline F5 & 9.15 & 115 & 56.6 & 120 & 0.36 & 41.8 & 111.8 & 2.7 \\
\hline F6 & 5.66 & 109 & 62.8 & 111 & 0.23 & 16 & 128 & 8 \\
\hline F8 & 6.57 & 102 & 77.9 & 124 & 0.37 & 21.6 & 129.2 & 6 \\
\hline H1 & 4.53 & 35 & 63.2 & 104 & 0.27 & 10.3 & 103.4 & 10.1 \\
\hline $\mathrm{H} 3$ & 2.17 & 23 & 69.9 & 32 & 0.76 & 2.4 & 49.7 & 21.1 \\
\hline H4 & 2.77 & 6 & 51.9 & 18 & 0.71 & 3.8 & 52.3 & 13.6 \\
\hline H5 & 9.8 & 55 & 58.3 & 74 & 0.44 & 48 & 70.3 & 1.5 \\
\hline \multicolumn{9}{|c|}{1 Jan 1999 to $30 \mathrm{Apr} 1999$} \\
\hline ECMWF winds & 4.85 & 228 & 18.8 & 108 & 0.95 & 11.8 & 27.3 & 2.3 \\
\hline P1 & 2.64 & 58 & 30.9 & 113 & 0.57 & 3.5 & 32.8 & 9.4 \\
\hline P2 & 1.84 & 82 & 33.4 & 93 & 0.4 & 1.7 & 27 & 16 \\
\hline F3 & 1.07 & 207 & 47.7 & 121 & 0.47 & 0.6 & 32.9 & 57.6 \\
\hline F4 & 0.84 & 169 & 45.4 & 117 & 0.54 & 0.4 & 30.6 & 86.6 \\
\hline F5 & 1.05 & 144 & 39.8 & 115 & 0.4 & 0.6 & 23.6 & 42.5 \\
\hline F6 & 2.69 & 59 & 50.6 & 120 & 0.36 & 3.6 & 115.2 & 31.8 \\
\hline F8 & 2.74 & 58 & 47 & 131 & 0.42 & 3.8 & 88.3 & 23.5 \\
\hline H1 & 2.49 & 358 & 38.5 & 112 & 0.41 & 3.1 & 62.8 & 20.3 \\
\hline H3 & 1.55 & 349 & 35 & 176 & 0.71 & 1.2 & 16.4 & 13.6 \\
\hline H4 & 1.67 & 352 & 39.7 & 8 & 0.69 & 1.4 & 25.3 & 18.1 \\
\hline H5 & 3.18 & 45 & 42.3 & 69 & 0.62 & 5 & 27.6 & 5.5 \\
\hline \multicolumn{9}{|c|}{1 May 1999 to $13 \mathrm{Sep} 1999$} \\
\hline ECMWF winds & 0.83 & 307 & 14.5 & 152 & 0.78 & 0.3 & 14.3 & 41.8 \\
\hline P1 & 3.61 & 111 & 29.4 & 108 & 0.28 & 6.5 & 13.2 & 2 \\
\hline P2 & 1.26 & 128 & 26.1 & 105 & 0.46 & 0.8 & 5 & 6.3 \\
\hline F3 & 5.86 & 140 & 42.7 & 133 & 0.35 & 17.2 & 17.9 & 1 \\
\hline F4 & 5.77 & 124 & 40.2 & 125 & 0.45 & 16.7 & 21.5 & 1.3 \\
\hline F5 & 5.59 & 136 & 39.5 & 132 & 0.37 & 15.6 & 18.6 & 1.2 \\
\hline F6 & 6.74 & 110 & 47.3 & 113 & 0.31 & 22.7 & 33.1 & 1.5 \\
\hline F8 & 5.12 & 105 & 44.2 & 122 & 0.45 & 13.1 & 26.6 & 2 \\
\hline H1 & 2.98 & 36 & 36.7 & 104 & 0.36 & 4.5 & 24.5 & 5.5 \\
\hline H3 & 1.12 & 49 & 35 & 16 & 0.84 & 0.6 & 10.4 & 16.8 \\
\hline $\mathrm{H} 4$ & 1.28 & 37 & 37.9 & 23 & 0.68 & 0.8 & 12.3 & 15 \\
\hline H5 & 6.85 & 59 & 38.2 & 61 & 0.39 & 23.4 & 16.7 & 0.7 \\
\hline
\end{tabular}

${ }^{a}$ Compare Table 1 for instrument depths. Except for the maximum current speed, the records have been 35 hour low-pass filtered before calculating these bulk statistics.

[30] Comparison in Table 3 of the paired temperature and salinity sensors on FTS6 and FTS8, separated vertically by 11 and $22 \mathrm{~m}$ respectively, suggests that some stratification persists near the polynya site even during periods in winter, when this stratification likely is maintained advectively. For example, the mean winter salinity difference between the lower and upper sensors was 0.14 at FTS6 and 0.10 at FTS8. Note also in Table 3 that maximum temperatures during winter exceeded $0^{\circ} \mathrm{C}$ at moorings F7, FTS8 (lower instrument), and H1. This suggests that some heat is still transported into the region in winter. Because the maximum winter temperatures recorded farther south at moorings $\mathrm{H} 3$ and $\mathrm{H} 4$ were much lower, within about $0.1^{\circ} \mathrm{C}$ of freezing, the warm winter water at F7, FTS8, and H1 could not have come from the south via the weak northward flow registered at the $\mathrm{H} 3$ and $\mathrm{H} 4$ moorings, but would instead have to have arrived via the (also weak) eastward flow from the Gulf of Anadyr. We will consider the maintenance of the regional temperature field further in section 4 .

[31] To illustrate the changing relationship between the various sources and sinks of salt in the region, Figure 6 shows the seasonal means of the salinity and velocity fields recorded at our moorings. During fall, the figure suggests that the regional salt balance is between the northward transport of relatively fresh water (seen at moorings $\mathrm{H3}$ and H4), and the eastward or southeastward flow of moderately saline water (seen at $\mathrm{H} 1$ and the various $\mathrm{P}$ and $F$ moorings). The fresh water from the southeast likely originated along the Alaskan coast, whereas the more saline water from the Gulf of Anadyr may have been upwelled onto the western Bering shelf. During the winter months with brine production (January-April), however, both the circulation and the salinity distribution change. The pronounced eastward flow at the $F$ moorings is replaced by weak and variably directed currents that may reflect haline forcing within the polynya (but note that the opposing northeast wind is also stronger during the winter). Concurrently, a large increase in the offshore salinity gradient characterizes the salinity field, with a strong salt source especially at P2. The latter source apparently overwhelms the advective freshening tendency of the northward flow registered at the southern moorings, and as a result the 


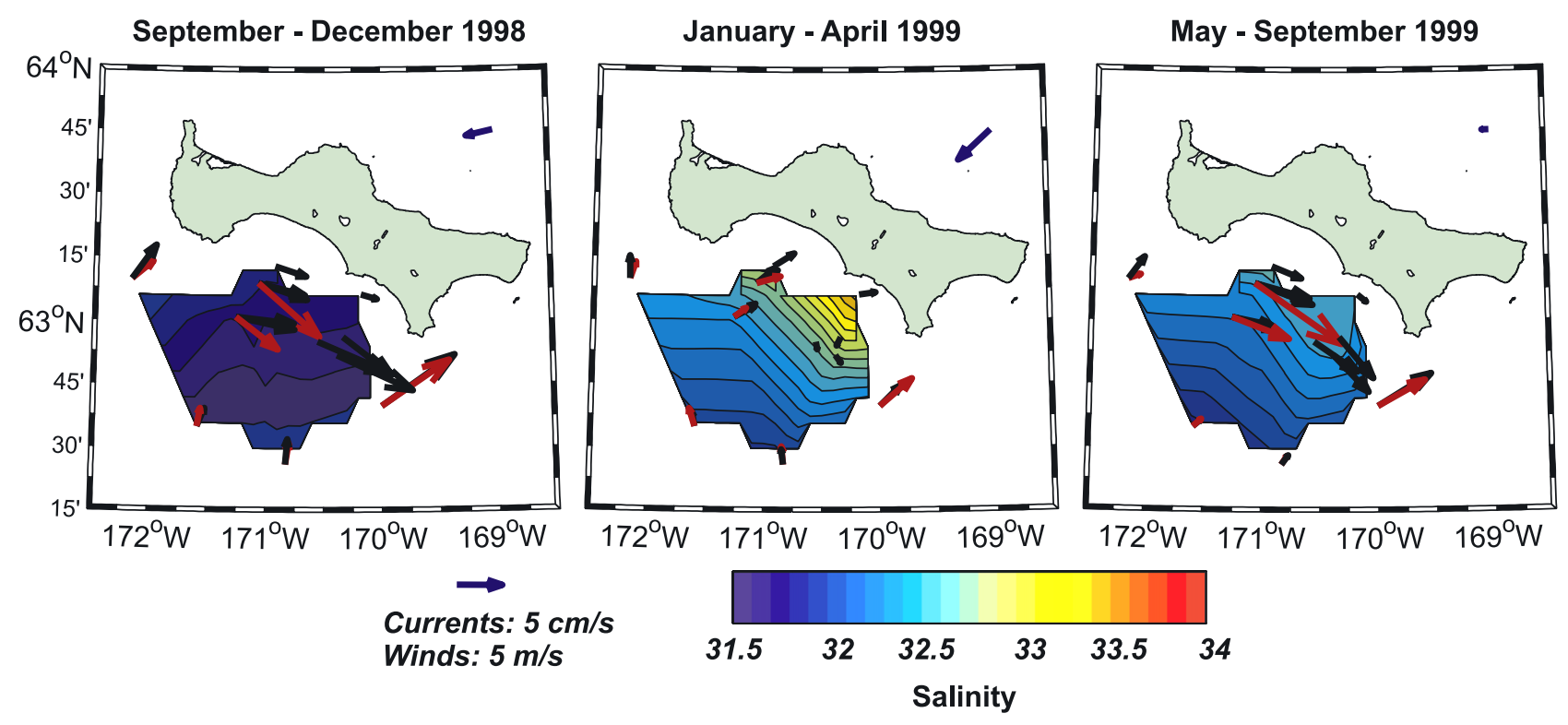

Figure 6. Seasonal mean velocity and interpolated salinity fields based on the moored measurements. For moorings with two mechanical current meters (H1-H5), black arrows denote the lower instrument and red arrows denote the upper. For moorings with ADCPs (F6 and F8), the black and red arrows represent bins with heights above bottom comparable to those at the $\mathrm{H}$ moorings. On each image the blue arrow in the upper right-hand corner represents the mean computed (rotated and scaled geostrophic) surface wind.

salinity throughout the region increases markedly over fall conditions. The saline polynya winter water likely passes northward through either Anadyr or Shpanberg Strait, depending on the direction of the flow south of St. Lawrence during and following a particular polynya event (compare Figure 11 and associated discussion). The water then continues northward through Bering Strait and into the Arctic Ocean [Weingartner et al., 2005; Woodgate et al., $2005 \mathrm{~b}$. In spring and summer, the stronger southeastward flow south of St. Lawrence resumes, importing waters of intermediate salinity from the Gulf of Anadyr and flushing any remaining saline polynya water, while the freshening tendency from the south continues.

[32] Table 4 further illustrates the seasonality of the velocity field. In general, the mean eastward currents decreased markedly from fall to winter, as is clear also from Figure 6. For example, the fall to winter velocity decrease at F3 and F4 (for the component normal to the P2F5 section line) averaged $7.3 \mathrm{~cm} \mathrm{~s}^{-1}$ (Table 4), while the corresponding seasonal decrease at the western line (P1F6-FTS8) was $4.4 \mathrm{~cm} \mathrm{~s}^{-1}$. During the same period the density gradient along the section lines increased (higher density to the north). If we take the deep seasonal mean salinity and temperature changes across each section (Table 3) to be representative of the changes higher in the water column, then the density gradient changes correspond to a change in the geostrophic velocity normal to the station line of $4.6 \mathrm{~cm} \mathrm{~s}^{-1}$ in the eastern section and $3.9 \mathrm{~cm} \mathrm{~s}^{-1}$ in the western section, surprisingly close to the observed velocity changes. This suggests that the regional flow pattern is affected by the density changes generated in the polynya in the manner that the model of Gawarkiewicz and Chapman [1995] predicts. There are two uncertainties in this calculation, however. The first is due to salinity errors. Applying the error estimates given in section 2.1 produces a maximum error in the seasonal mean geostrophic velocity change of about $1 \mathrm{~cm} \mathrm{~s}^{-1}$. The second uncertainty arises from applying the observed deep density changes to the entire water column. This could conceivably introduce a large error in the geostrophic estimate that is impossible to assess in a meaningful way with the present data set. We are necessarily left, then, with the need for caution in assessing the apparent agreement between seasonal changes in velocity and density gradient.

[33] Another perspective on the issue is provided by comparing the time series of vertical shear at F6 with the density difference between P1 and FTS8. This shows that the two series are weakly, but significantly correlated during winter ( $r=0.35$, with the expected sign), although they are uncorrelated during the fall. Accordingly, only about $10 \%$ of the variance of vertical shear at F6 during winter can be accounted for by the variability of the horizontal density gradient.

[34] Further comparison of the seasonal shear structure shows that the mean shear in the bottom half of the water column during fall, winter and summer is indistinguishable at the $95 \%$ confidence level, as is the case when comparing fall/winter and summer/fall upper layer mean shear. In the upper layer during summer, however, there is significantly more shear than in winter, which we attribute to the development of the summer pycnocline. From ADCP mooring F6, Figure 7 shows details of the winter nearbottom current and shear computed over a $10 \mathrm{~m}$ interval. The rectangular boxes correspond to the polynya events identified by Drucker et al. [2003]. The figure shows that the frazil polynya events correspond with an inshore flow at depth, but without significant shear, either during or immediately following the events. 


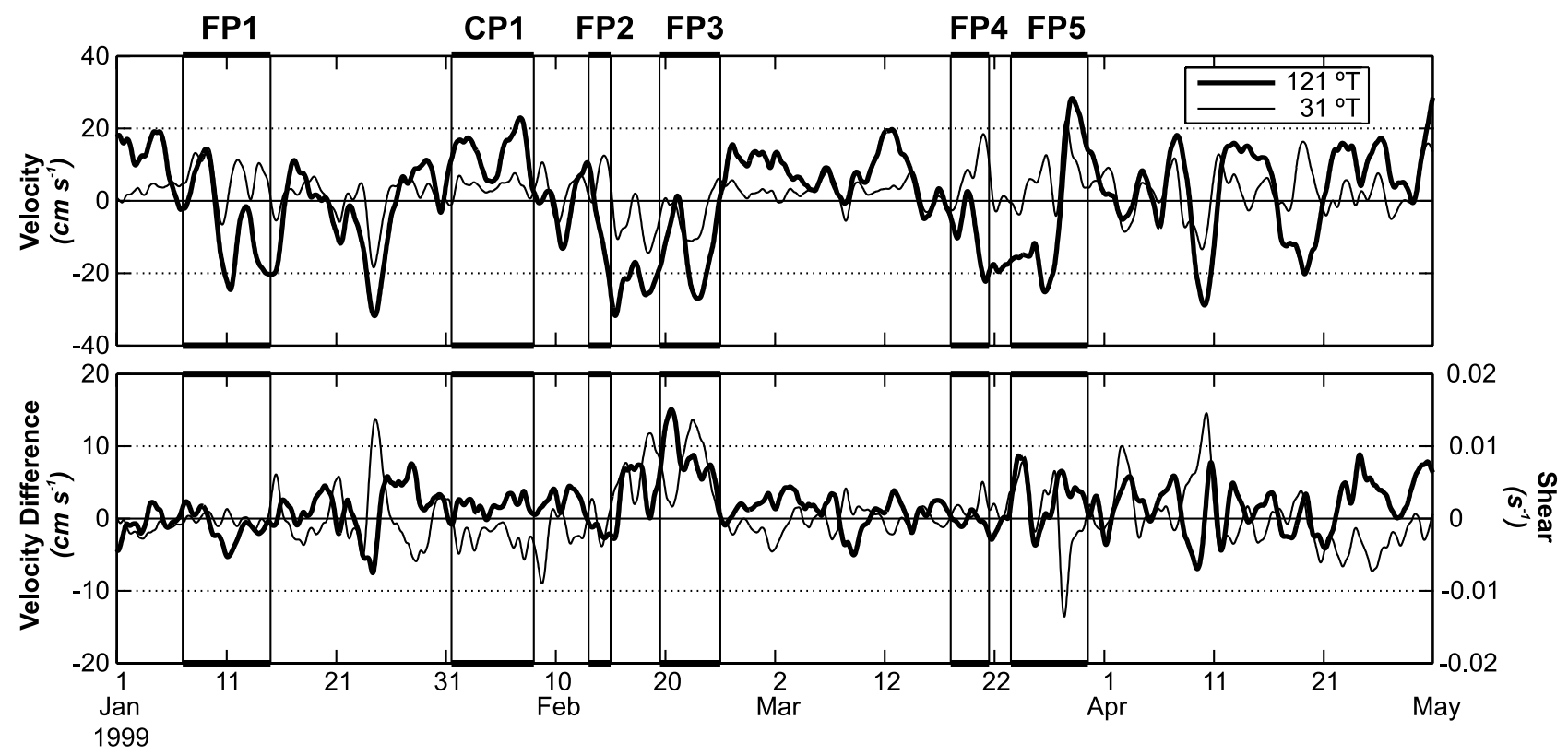

Figure 7. (top) Currents at ADCP mooring F6 during January-April from the deepest (37 m) bin. (bottom) Velocity difference and shear between the $27 \mathrm{~m}$ bin and the $37 \mathrm{~m}$ bin. Thick (thin) lines denote the along- (cross-) principal axis direction. The boxed and labeled periods, beginning with FP1, denote the observed frazil (FP) or congelation (CP) polynya events described by and adapted from Drucker et al. [2003, Figure 3].

[35] Effectively, then, the flow in the vicinity of the polynya appears to behave only modestly as predicted by geostrophic adjustment to the polynya-generated density field, with most of the flow variance having other origins. Regardless of the mechanisms responsible for the seasonal flow variability, however, the winter decrease in net flow south of the island was more pronounced at the eastern moorings (F3-F5, H5) than at the western ones (F6, F8, H1). This suggests a seasonal reorganization of the flow over the shelf, and in particular an altered partitioning of northward flow through Anadyr and Shpanberg straits. We consider this further in the Discussion section.

[36] The subtidal variance of the flow, given in Table 3 as the mean eddy kinetic energy (MEKE), also decreased from fall to winter, which is the opposite to what we would expect from a winter regime in which eddy fluxes are large [e.g., Gawarkiewicz and Chapman, 1995]. Note further that this seasonal decline in MEKE was with one exception (at P2) much larger at the eastern moorings than at the western ones, i.e., the spatial distribution of MEKE changed in the same sense as the mean flow. Since the MEKE of the wind field decreased only modestly from fall to winter (Table 3), it is likely that these seasonal changes in eddy energy are oceanic in origin, relatively small, and follow the magnitude of the seasonal mean flow. Note further that in contrast to the changes in velocity variance, the variance of the offshore density gradient about doubles from fall to winter, and that the increase is largest on the eastern (P2) line. These features suggest that eddy energy is not associated with the density field, and in particular that the winter buildup of salinity in the polynya does not result in large eddy fluxes.

[37] The empirical orthogonal function (EOF) representations of the seasonal velocity field (Figure 8 and Table 5) show that the first mode, representing nearly $60 \%$ of the variance, explains much of the alongshore variability except at P2. Mode 2 largely captures east-west asymmetry of the current field and mainly projects onto moorings $\mathrm{P} 2$ in fall $(38 \%)$ and winter $(66 \%)$, and onto H5 in summer $(31 \%)$. There is relatively little seasonal variation in the modal structure, again suggesting that eddy activity is not noticeably enhanced in winter. For the winds, mode 1 describes a NE/SW pattern of fluctuations, while the larger mode 2 describes a more meridional pattern.

[38] Table 5 shows that in fall, mode 1 represents moorings $\mathrm{P} 1$ and $\mathrm{F} 3-\mathrm{F} 8$ well $(73-86 \%$ of the variance), but represents the far-field moorings $\mathrm{H} 1-\mathrm{H} 5$ somewhat less so $(56-67 \%)$. Only in fall is mode 3 well resolved, when it accounts for $31 \%$ of the variance at $\mathrm{P} 2$. The fall winds are primarily resolved by the first two modes, with mode 3 contributing $10 \%$.

[39] During winter, mode 1 captures $48-74 \%$ of the current variance at all moorings except at P2 (1\%), which is well represented by mode 2 . The latter mode also explains a moderate amount of variance at P1 (22\%) and H5 (24\%). This suggests that dense polynya water is advected alongshore and out of the mooring domain, rather than cross-shore and past the frontal moorings F3-F5. There is a gap of $\sim 30 \mathrm{~km}$ between H5 and Southeast Cape on St. Lawrence Island, so it is possible that some of the eastward flowing dense polynya water may have escaped undetected.

[40] In summer, mode 1 more evenly represents all moorings (44-80\% of the variance), but not the winds (11\%). Winds are best represented by mode $2(35 \%)$, which also captures $18-31 \%$ of the variance at moorings $\mathrm{P} 2, \mathrm{H} 3$, $\mathrm{H} 4$ and H5. Given that the water column is well stratified in summer and that currents are measured close to the bottom, the poor correlation between wind and current is not 

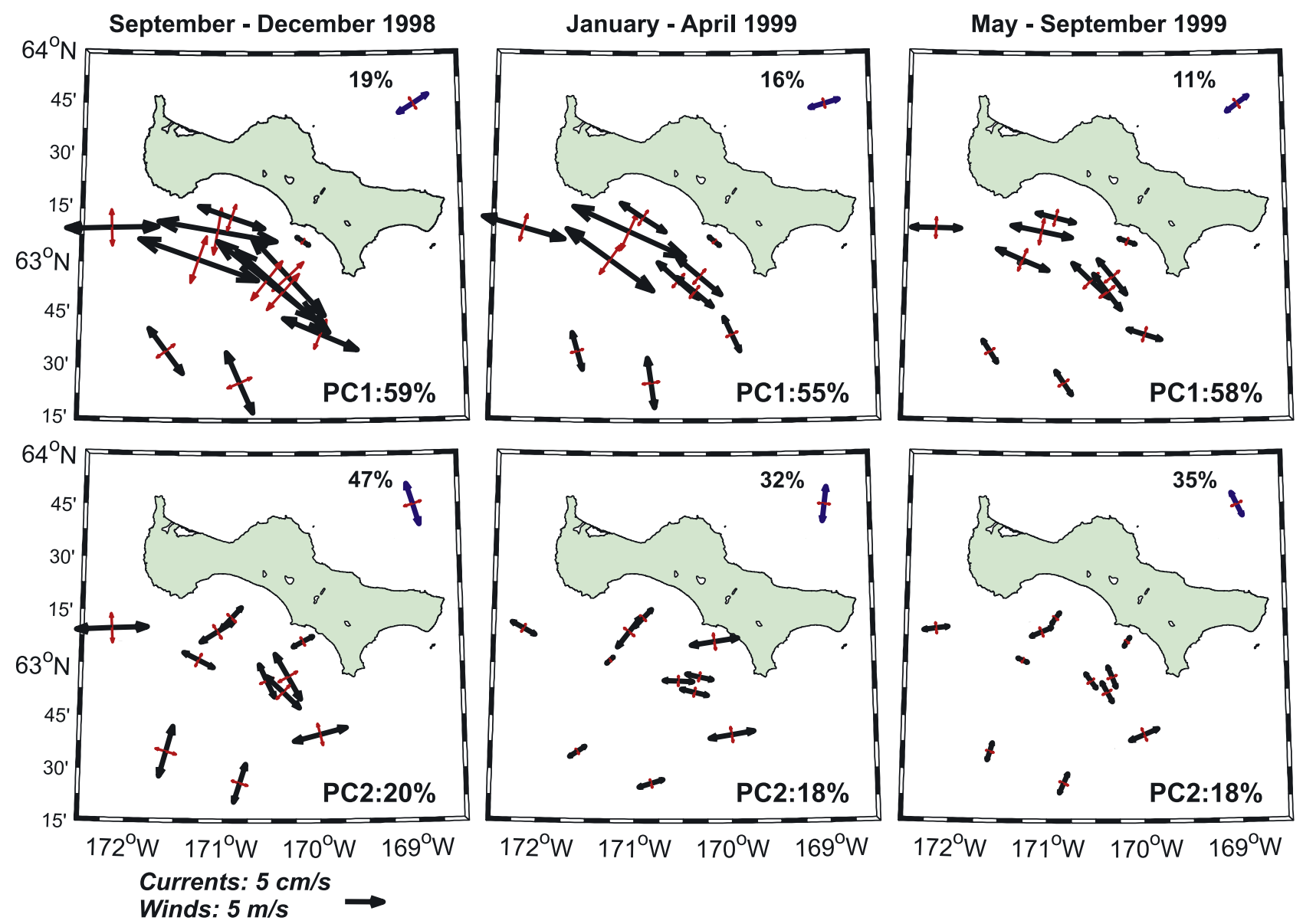

Figure 8. Results of the complex empirical orthogonal function (EOF) analysis of the current and wind time series for each of the three seasons. The vectors show the projection of the first two eigenvectors onto the modal amplitude time series, with black depicting the current principal axis magnitude and red depicting the off-axis magnitude. The blue and red vector pairs in the upper right-hand corner of each panel are the corresponding projections for the wind time series. The number in the lower right-hand corner of each panel is the percent variance explained by that mode; the number above the wind vector is the corresponding percentage for the wind variance. See also Table 5.

surprising. In particular, the F moorings, which observed the strongest eastward flow, do not fluctuate with the summer winds, although the far-field H3-H5 moorings do slightly. In general, the correlation between the current records and the wind is modest in both winter and summer, with over $50 \%$ of the wind variance left unresolved by the EOF analysis.

\subsection{Ocean Response to the St. Lawrence Polynya}

[41] Figure 9 shows the winter atmospheric forcing of the polynya region in the form of wind direction, speed, and air temperature, and the salinities measured at the nearshore moorings $\mathrm{P} 1$ and $\mathrm{P} 2$. The highlighted periods refer to the presence of polynyas identified from advanced very high resolution radiometer (AVHRR) and synthetic aperture radar (SAR) imagery by Drucker et al. [2003]. The letters FP denote frazil polynya events, as illustrated by Figure 2 . The letters CP identify a columnar ice polynya. This formed under weak winds and very low temperatures, so that frazil ice only occurred very close to the coast, while the rest of the polynya contained thin columnar ice. Both the longest frazil event, FP1, and the columnar event, CP1, lasted eight days, while the shortest event, FP2, lasted two days. The duration of these events is important for our later comparison with the timescale of the oceanic response.

[42] Suitable satellite imagery is lacking for April, but northerly winds in excess of $10 \mathrm{~m} \mathrm{~s}^{-1}$ during $1,4-5,8-9$, $11-12,16-20$, and 29 April together with temperatures generally below $-10^{\circ} \mathrm{C}$ suggest that polynyas were likely present much of the month. The prolonged saline event at P2 during the first half of April, when air temperatures were still low, accords with this suggestion. Note in Figure 9 that the salinities recorded at the two polynya moorings differ substantially, with the eastern record (P2) being the more saline, typically peaking during or after a cold offshore wind event, while the western record (P1) is generally less clearly tied to the atmospheric forcing. This difference may in part reflect the topographic relief upwind of P1 (Figure 5) as suggested by the polynya generally being narrower in this region [Walter, 1989]. The salinity difference may also reflect local differences in the background circulation field at the two sites.

[43] Figure 10 shows the winter time series of salinity and velocity in the eastern mooring section (P2, F5, and H4), 
Table 5. Percent Variance Explained by the EOF Analysis in Each Season and for All Resolved Modes ${ }^{\mathrm{a}}$

\begin{tabular}{|c|c|c|c|c|c|c|c|c|c|c|}
\hline \multirow[b]{2}{*}{ Data Set } & \multicolumn{4}{|c|}{14 Sep 1998 to 31 Dec 1998} & \multicolumn{3}{|c|}{ 1 Jan 1999 to 30 Apr 1999} & \multicolumn{3}{|c|}{1 May 1999 to 13 Sep 1999} \\
\hline & PC1 & $\mathrm{PC} 2$ & PC3 & Unresolved & $\mathrm{PC} 1$ & $\mathrm{PC} 2$ & Unresolved & $\mathrm{PC} 1$ & $\mathrm{PC} 2$ & Unresolved \\
\hline Total variance & 59 & 20 & 8 & 13 & 55 & 18 & 27 & 58 & 18 & 24 \\
\hline ECMWF winds & 19 & 47 & 10 & 24 & 16 & 32 & 52 & 11 & 35 & 54 \\
\hline $\mathrm{P} 1$ & 73 & 11 & 1 & 15 & 48 & 22 & 30 & 75 & 9 & 16 \\
\hline $\mathrm{P} 2$ & 16 & 38 & 31 & 15 & 1 & 66 & 33 & 44 & 20 & 36 \\
\hline F3 & 75 & 15 & 0 & 10 & 68 & 4 & 28 & 71 & 14 & 15 \\
\hline F4 & 84 & 7 & 1 & 8 & 73 & 4 & 23 & 76 & 7 & 17 \\
\hline F5 & 84 & 10 & 0 & 6 & 67 & 8 & 25 & 70 & 12 & 18 \\
\hline F6 & 84 & 6 & 1 & 9 & 63 & 14 & 23 & 77 & 8 & 15 \\
\hline F8 & 86 & 2 & 0 & 12 & 70 & 4 & 26 & 80 & 1 & 19 \\
\hline H1 & 57 & 14 & 1 & 28 & 58 & 7 & 35 & 63 & 9 & 28 \\
\hline H3 & 56 & 20 & 12 & 12 & 59 & 7 & 34 & 49 & 18 & 33 \\
\hline H4 & 67 & 11 & 7 & 14 & 74 & 6 & 20 & 49 & 23 & 28 \\
\hline H5 & 63 & 20 & 1 & 16 & 50 & 24 & 26 & 50 & 31 & 19 \\
\hline
\end{tabular}

${ }^{\text {a }}$ The computation matrix included the (near-bottom and tidally filtered) current meter records given in Table 3 and the ECMWF wind time series. To ensure equal weighting for all records, the time series were normalized to have zero mean and unity standard deviation.
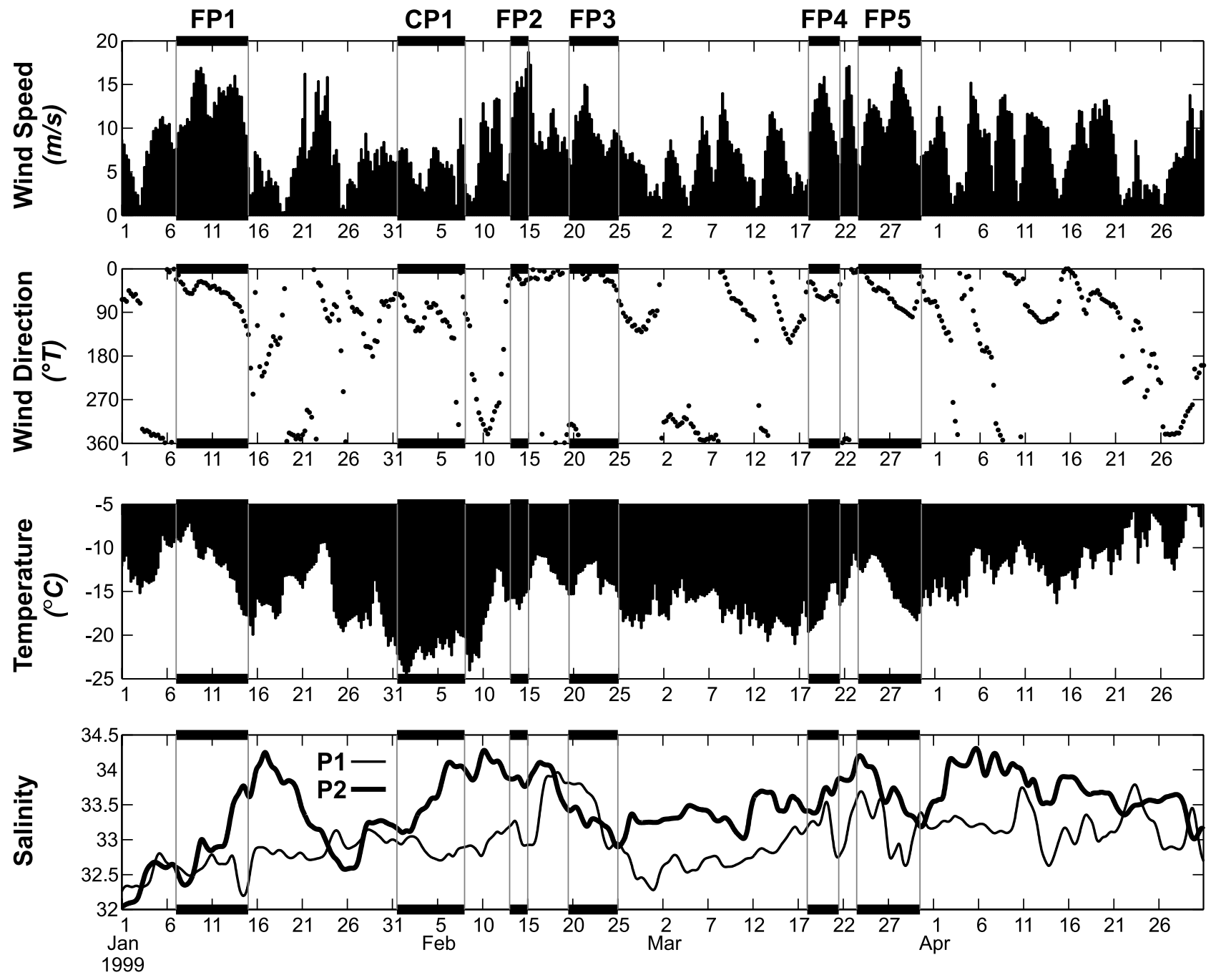

Figure 9. Wind speed, direction, air temperature, and salinity at sites P1 and P2 during January-April 1999. Wind vectors are rotated geostrophic winds computed from European Centre for Medium-Range Weather Forecasts (ECMWF) pressure fields centered on $64.36^{\circ} \mathrm{N}, 171.00^{\circ} \mathrm{W}$. Temperatures are from the International Arctic Buoy Program $2 \mathrm{~m}$ surface air temperature archive, interpolated to $62.71^{\circ} \mathrm{N}$, $170.54^{\circ} \mathrm{W}$. The boxed and labeled periods, beginning with FP1, denote the observed FP or CP polynya events described by and adapted from Drucker et al. [2003, Figure 3]. 


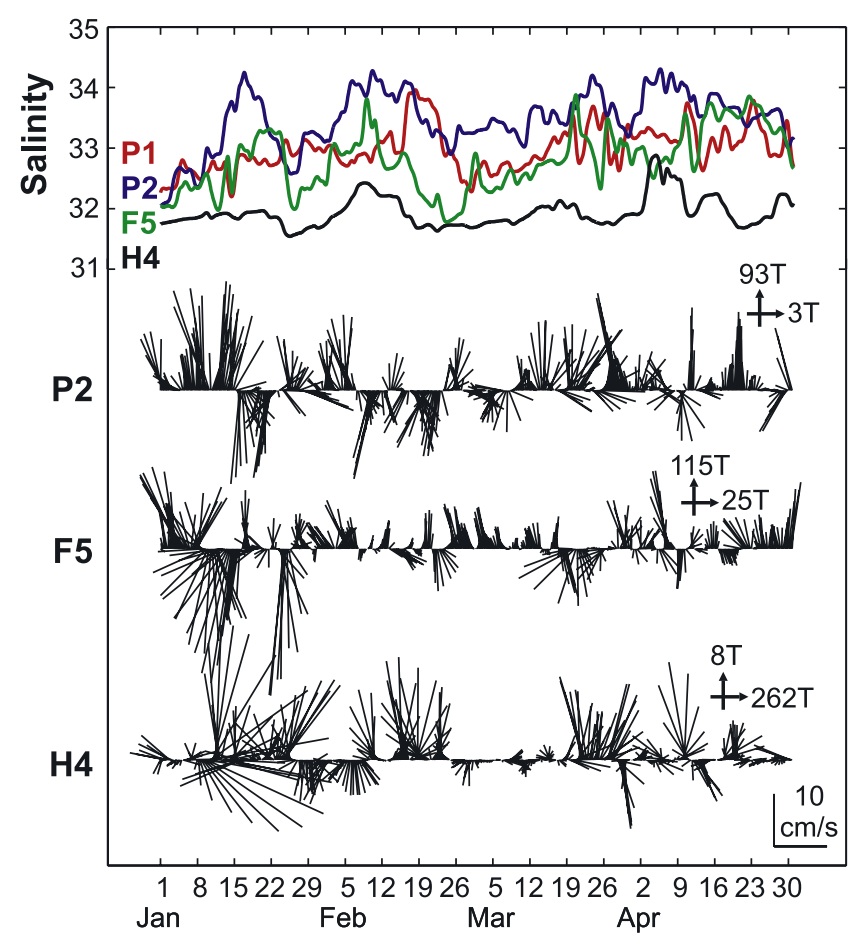

Figure 10. Salinity and velocity in the eastern mooring cross-shore section (P2, F5, H4) and salinity at P1 during winter based on low-pass filtered data. To emphasize current fluctuations, velocity sticks are oriented so that upward, i.e., perpendicular to the time axis, is aligned along the principal axis of variation.

where the winter salinity increase was largest, as well as the salinity at the western polynya mooring (P1). All these sites exhibit an increasing salinity trend until at least the beginning of April, typically 1 over the course of the winter, except for the far-field (H4) mooring, where the salinity increase was considerably less. A net local salinity increase of 1 solely due to freezing would represent the formation of about $1.7 \mathrm{~m}$ of ice. This does not account for salt export during the winter months, however, nor for any salt flux convergence associated with the flow field. At the polynya moorings (P1, P2), essentially all the net salting has been accomplished by the end of March, while at F5 the salinity continues to increase markedly in April. Note that both at the beginning of winter ice formation and at the end the differences in salinity between the three $\mathrm{P}$ and $F$ moorings shown in Figure 10 are small, while they are generally large during the intervening three months. The overall impression is that during most of the period with active freezing, sizable density gradients are created either by the surface forcing in the polynya or by the ocean response to that forcing. The heterogeneity of the winter density field is shown by only the P2 record being significantly correlated with the other three salinity time series in Figure 10, and that even then P2 accounts for only $18-32 \%$ of the unlagged variance at those other moorings (lagged correlations are not greatly different). Indeed, note that in Figure 10, even for the very large FP5 event in late March when the polynya extended far south of mooring F5 [cf. Drucker et al., 2003, Figure 2c], the salinity time series show poor agreement.
[44] Figure 11 shows the mean velocity and salinity during the six January-March polynya events identified by Drucker et al. [2003]. The mean wind forcing during the five FP events was similar, with moderately strong NE winds, albeit of varying duration (compare Figure 9), while CP1 had much weaker winds with a small westerly component. Details of both flow and salinity vary considerably, but four of the five FP events involve westward flow in the lower water column, especially at the $F$ moorings, consonant with the predictions of theory [Gawarkiewicz and Chapman, 1995] (but compare our earlier caveats). In these events, the three strongest westward flows observed at the western moorings (H1, F6, F8) are associated with the three wind vectors with the largest westward component. In contrast, events FP5 and CP1 appear to discharge their salt burden eastward into Shpanberg Strait. The considerable differences between the various events, as well as the relatively weak wind-current coupling, suggest that the local topographically influenced wind field is more important in forcing the flow field than the regional winds. This local wind field not only disperses the dense waters produced under the polynya, but also contributes to the local salt balance through its role in importing waters of various salinities.

\subsection{Winter Salt Balance}

[45] The velocity measurements have neither the accuracy nor the vertical and horizontal resolution to allow direct estimation of the components of the salt balance. We can, however, estimate the combined effect of the winter surface salt flux and the convergence of the advective salt flux, based on the net salting of the water column over the winter, and then compare that salinity increase with the ice growth estimates of Drucker et al. [2003].

[46] We assume that at least for strong frazil events, the water is at the freezing point, so that all of the heat loss to the atmosphere results in ice formation. There are two lines of evidence for this. First, Drucker et al. [2003, Figure 3] suggests that strong frazil polynya events are accompanied by sonar reflections at depth, likely from frazil ice, requiring the water to be near freezing. Second, for the same events, moorings P1 and P2 show deep temperatures very close to freezing, indeed, at P2, possibly supercooled relative to surface pressure. Under this assumption, Drucker et al. [2003, Table 2, section 6] give a cumulative ice growth in the polynya region during events FP1 through FP5 of $2.7 \mathrm{~m}$ (January-March). This assumes ice formation at other times is negligible, including during the $\mathrm{CP} 1$ event, and the $2.7 \mathrm{~m}$ is therefore an underestimate. Because the frazil polynya timing is defined in part by the ULS observations at F3 and F5, we apply our estimated minimal ice growth to the F3$\mathrm{F} 4-\mathrm{F} 5$ triangle.

[47] Figure 12 shows the annual evolution of the deep mean salinity both for the F3-F4-F5 triangle and the entire area covered by the mooring array. For the latter, the April salinity increase is modest, suggesting that ice formation is reduced from that of the earlier three months. Lacking better information, we assume the April ice formation rate to be one-half that during January-March, giving a total cumulative winter (January-April) ice formation of $3.2 \mathrm{~m}$ within the F3-F4-F5 triangle. To extrapolate this rate to the entire mooring array, we note that the 4 month trend line for the 

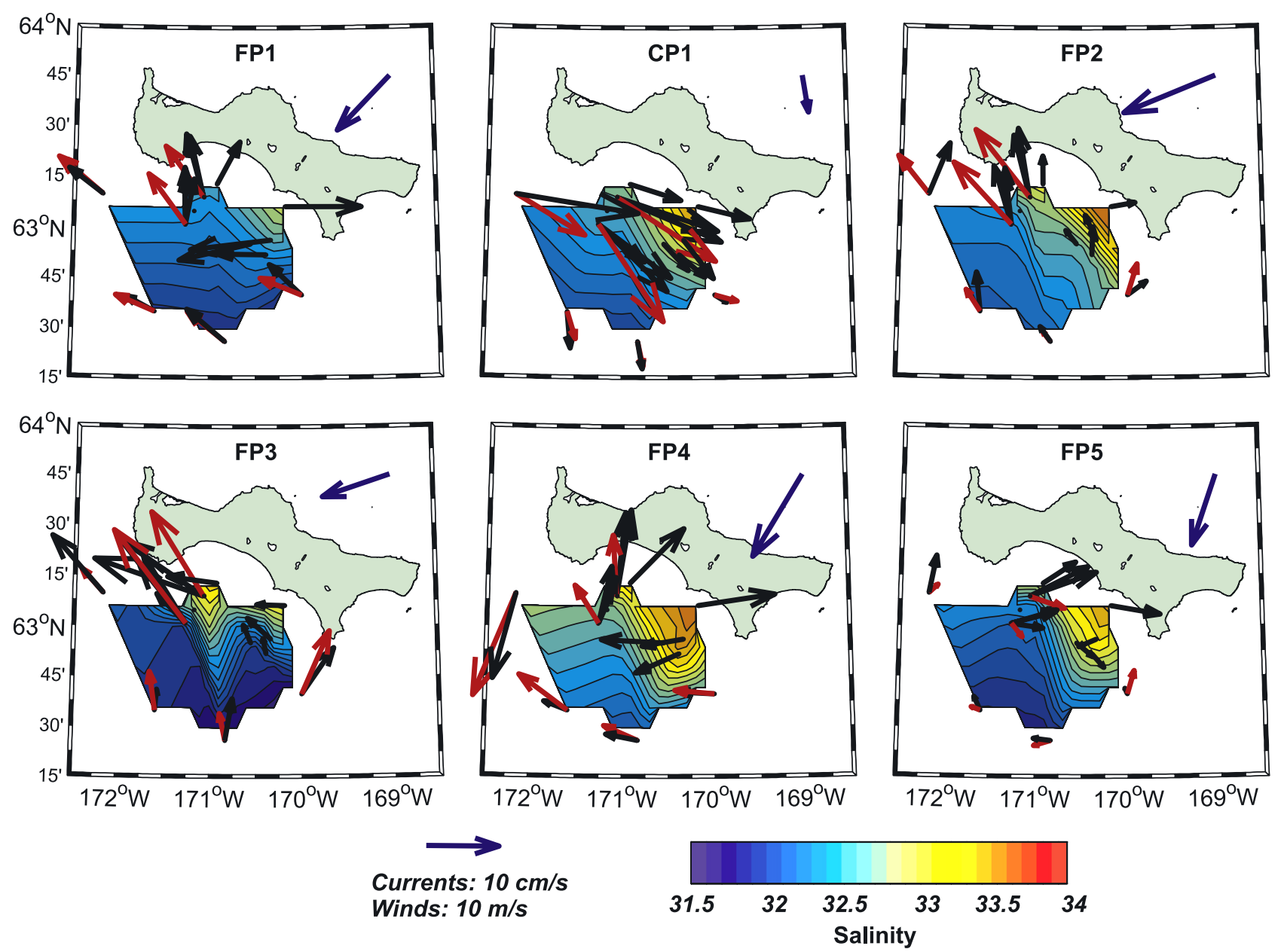

Figure 11. Mean currents, salinity, and wind vectors during each of the polynya events identified in Figures 7 and 9. Color scheme as in Figure 6.

entire array gives a salinity increase of $\sim 0.4$, whereas over the F3-F4-F5 triangle the increase is $\sim 0.9$. Correcting for the difference in water depth and assigning all of the areal difference in salinity increase to differences in ice production, we estimate that the winter ice formation over the whole mooring array is half that over the F3-F4-F5 triangle, i.e., $\sim 1.6 \mathrm{~m}$. For a water depth of $50 \mathrm{~m}$, an initial salinity of 32.3 , an ice density $90 \%$ of the water density, and a bulk ice salinity of 7 , the $1.6 \mathrm{~m}$ of ice formation would increase the salinity of the underlying water by 0.8 .

[48] Since the observed salinity increase over the entire array is only 0.4 , we estimate the advective effect (due to horizontal salt flux convergence) as -0.4 over the four winter months, i.e., the advective freshening tendency is about half the salinization tendency due to freezing. The parallel calculation for the F3-F4-F5 triangle (for which the observed salinity increase is 0.9 ) gives a salinity increase tendency of 1.8 due to the estimated ice formation over the winter and an advective freshening tendency of -0.9 , again about half the salinization tendency due to freezing. These advection estimates represent the net effect of importing low-salinity waters and exporting saline waters, and we expect them to be somewhat low, since they do not account for any ice formation outside the identified polynya periods. For comparison, the salinity decrease

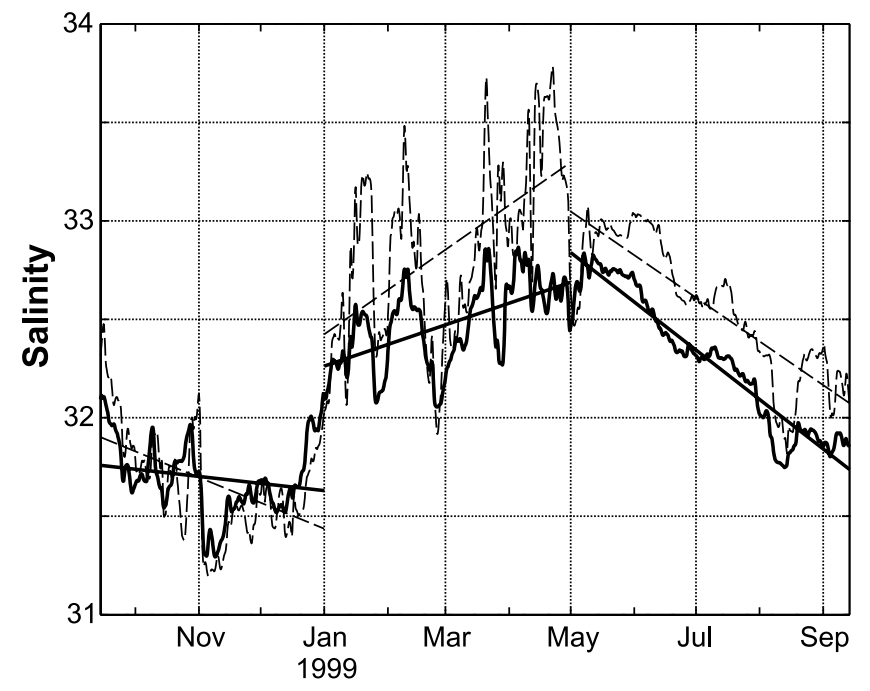

Figure 12. Mean spatially interpolated salinity over the entire St. Lawrence polynya array (solid line) and over the F3-F4-F5 triangular subarray (dashed line) during September 1998-September 1999. The full array compilation represents $\sim 6500 \mathrm{~km}^{2}$, and the subarray represents $\sim 41 \mathrm{~km}^{2}$. The straight lines are the seasonal trends for each array. 
during the four months following the freezing season (May-August) is about 1, both for the entire array and for the F3-F4-F5 triangle.

[49] We have also calculated the mean and eddy salt fluxes at each mooring over the winter, i.e., the 4 month mean velocity/salinity product and the correlated (averaged) $v^{\prime} S^{\prime}$ product, where $v^{\prime}$ and $S^{\prime}$ are the instantaneous departures from the mean. We find that the eddy salt flux is typically between $3 \times 10^{-3}$ and $10^{-2}$ of the mean, and only at moorings F4 and F5 is it as high as $1.4 \times 10^{-2}$ of the mean. This negligible eddy flux is of course contrary to the predictions of the Gawarkiewicz and Chapman [1995] model.

[50] In summary, for the four winter months we find that the freshening effect of advection is of first order in the salt budget, even if the surface brine flux resulting from freezing overwhelms it by a factor of two. On the other hand, the effect of eddy salt fluxes is negligible.

\section{Discussion}

[51] In this final portion, section 4.1 utilizes dimensional scalings and dynamical considerations to complete the model-observation comparison; section 4.2 examines the role that this polynya plays in establishing the regional heat and salt budget; section 4.3 looks ahead to future observational and modeling efforts that will further extend the story of the northern Bering Sea oceanography.

\subsection{Implications for Modeling}

[52] The theoretical response to a continuous, negative buoyancy forcing over latent heat polynyas (having either steady or time-varying shape) over gently sloping continental shelves in the absence of a background flow field consists of several steps [Gawarkiewicz and Chapman, 1995; Chapman and Gawarkiewicz, 1997; Chapman, 1999]. During the initial geostrophic adjustment phase, dense water accumulates within the polynya, leading to flow along the front that develops at the offshore perimeter of the polynya. Throughout this initial phase, no water is exported from the polynya, so that the density anomaly within the polynya increases linearly with time and inversely with bottom depth. For typical polynya widths and buoyancy forcing, the timescale of the adjustment phase is 5-10 days. During the second phase, buoyancy forcing continues and the geostrophic flow along the front interacts with the coast, initiating large ageostrophic velocities to satisfy the coastal constraint. The ageostrophic response generates frontal meanders that during the third phase develop into eddies, which detach from the front and propagate slowly (1$2 \mathrm{~cm} \mathrm{~s}^{-1}$ ) offshore across isobaths. The eddy shedding and offshore buoyancy flux halts further growth of the density anomaly within the polynya. The system then comes into equilibrium, with the cross-isobath eddy buoyancy flux balancing the surface buoyancy flux.

[53] In contrast to the theoretical prediction that dense water is carried across isobaths by eddies, we found negligible cross-shelf eddy density fluxes, and indeed low levels of eddy energy everywhere (actually decreasing from fall to winter), even though dense water accumulates within the polynyas and large cross-shore density gradients develop. Fluctuations in density appear to be tied more closely with polynya openings and advective flushing rather than attainment of an equilibrium state and shedding of eddies.

[54] The equilibrium timescale is $t_{e}=\beta\left(f W b / B_{0}\right)^{1 / 2}$, where the constant $\beta$ is $\sim 3 ; f$ is the Coriolis parameter $(1.3 \times$ $\left.10^{-4} \mathrm{~s}^{-1}\right) ; b$ is the width of the active polynya $(\sim 25 \mathrm{~km}$ from Drucker et al. [2003]) within which the surface buoyancy flux, $B_{0}$, occurs; and $W$ is the width of the forcing decay region over which $B_{0}$ decreases from its maximum value over the open water portion of the polynya to near zero where the concentration and thickness of sea ice effectively arrests the surface buoyancy flux. For polynyas whose size varies with time and/or intermittent polynyas, which open and close completely, $W$ is equivalent to the range in polynya width [Chapman, 1999]. Accordingly, we set $W \sim 25 \mathrm{~km}$ for the St. Lawrence Island polynya. During the observed polynya events, $B_{0}$ is $\sim 4 \times 10^{-7} \mathrm{~m}^{2} \mathrm{~s}^{-3}$ so that with the values of the other parameters, $t_{e}$ is $\sim 15$ days, although we note for the reasons discussed by Chapman [1999] that the $t_{e}$ scaling may not strictly apply to intermittent polynyas. Our estimate of $t_{e}$ is a minimum, because the appropriate $B_{0}$ is the time-averaged surface buoyancy forcing for intermittent polynyas, with the averaging interval including periods when the polynya is closed [Chapman, 1999]. Consequently, $B_{0}$ is smaller than given above, because the buoyancy flux decays exponentially with ice thickness, being roughly half the open water value for an ice thickness of $0.3 \mathrm{~m}$ [Maykut, 1986]. The observed ice thickness during closure of the St. Lawrence polynya ranges from 0.3 to $1.5 \mathrm{~m}$ [Drucker et al., 2003]. Assuming that zero buoyancy flux occurs during polynya closures, a lower limit for $B_{0}$ is then $\sim 1 \times 10^{-7} \mathrm{~m}^{2} \mathrm{~s}^{-3}$, which implies an upper bound for $t_{e}$ of $\sim 30$ days.

[55] The Gawarkiewicz and Chapman [1995] model results do not change appreciably in the presence of spatially uniform, constant, alongshore ambient flows [Chapman, 2000]. These flows do not suppress instabilities, but simply advect the unstable front downstream, so that if the ambient current is sufficiently strong, the eddies form downstream and outside of the polynya. This occurs if $t_{e}$ exceeds the advection timescale [Chapman, 2000], e.g., $t_{e}>$ $L_{p} / U$, where $U$ is the magnitude of the along-coast flow and $L_{p}$ is the polynya length, here taken as $\sim 100 \mathrm{~km}$. Our results (Figures 7 and 8) imply that $L_{p} / U$ is $\sim 10-20$ days, which is comparable to (or possibly somewhat shorter than) the expected $t_{e}$. If an eddy formed in the vicinity of either F-array it would, at a cross-shore translation speed of $2 \mathrm{~cm} \mathrm{~s}^{-1}$, move offshore $25 \mathrm{~km}$ and alongshore $\sim 140 \mathrm{~km}$ in $\sim 15$ days. This offshore distance does not extend beyond the $\mathrm{H}$ moorings, but the alongshore displacement is sufficient to have advected the dense water into either Shpanberg or Anadyr straits. Conceivably, then, eddies formed in these straits or even farther downstream of them, as the dense water flowed northward toward Bering Strait. Roach et al. [1995] found virtually no winter salinity difference between the east and west channels of Bering Strait, suggesting either that dense water escaping the polynya mixes laterally before arriving at the strait, or its signature is lost because of additional buoyancy fluxes elsewhere.

[56] There are, however, additional mechanisms that could affect either $t_{e}$ or the stability properties of the dense water front. For example, ambient currents supply the polynya with lower-salinity water and advect the dense 
water away, limiting the growth of the density anomaly and perhaps leading to frontal stabilization [Chapman, 2000]. The model instabilities are initiated by ageostrophic flows where the front intersects the coast. If the front is not attached to the coast of St. Lawrence Island, but instead extends beyond the edges of the island, ageostrophic currents may not develop. Figure 3 and other images shown by Drucker et al. [2003], however, indicate that with the possible exception of a detached boundary to the west, the polynya boundary generally does intersect the coast. Baroclinic instabilities do develop along the rim current surrounding chimneys in open ocean convection, where no coast is present [e.g., Visbeck et al., 1996, and references therein]. Moreover, ambient flows, tides, and wind forcing, which are not included in the theory, may all in principle initiate instabilities if the front is inherently unstable. It therefore seems likely that the instabilities would evolve even if the coastal constraint were absent in the St. Lawrence polynya, although $t_{e}$ might well change in the absence of a coastal boundary.

[57] We have also considered stability conditions directly and investigated whether or not the observed circulation field could be unstable. In the January-April mean, the horizontal and vertical velocity gradients are small (Figure 6) suggesting negligible winter-averaged potential vorticity gradients. However, we find periods lasting from 2 to 10 days during which there is substantial meridional shear, of order $10^{-5} \mathrm{~s}^{-1}$ in the alongshore flow. Such events involve alongshore jets that have maximum eastward (or westward) velocities centered at or near the F moorings, with weaker flow to the north and south. Under such conditions the meridional potential vorticity gradient reverses sign, so that a necessary condition for instability is satisfied. While the meridional shear will enhance the likelihood of barotropic instability, it might also broaden or otherwise distort the density front. Furthermore, the alongshore flows are divergent and vary rapidly in time, leading to additional frontal distortion. The net effect of these processes on the stability of the front is unclear.

[58] Following Pedlosky [1987] and using the range of buoyancy frequency $N^{2}(z)$ and background velocities suggested by the data, Eady model calculations suggest that the most rapidly growing unstable waves have $e$-folding growth rates of $\sim 2$ days, similar to the rates obtained by Gawarkiewicz and Chapman [1995]. Applying quasigeostrophic instability theory to the polynya setting is of course problematic given the shallowness of the shelf and the rapidly varying nature of the ambient circulation field and surface forcing. We note in particular that the growth rate will be smaller in the presence of surface and bottom Ekman layers if these are not small compared to the total water depth [Pedlosky, 1987]. The model develops a thin bottom boundary layer (associated with a linear friction law), but for the Bering shelf, the bottom boundary layer shear associated with the clockwise component of the $M_{2}$ tidal current encompasses the entire water column [Danielson and Kowalik, 2005]. Moreover, the model does not include a surface Ekman layer, which likely extends over a considerable portion of the water column in winter when the stratification is weak. Consequently, the bottom and surface boundary layers overlap, possibly reducing the instability growth rate and thereby increasing $t_{e}$.
[59] Despite the existence of conditions seemingly conducive to instability formation, we did not find supporting evidence. We conclude that either no instabilities formed or they were advected downstream and out of the sampling array prior to formation.

\subsection{Significance of the Polynya to the Bering Shelf Heat and Salt Balance}

[60] While the St. Lawrence polynya feeds saline water to the northward flow through Bering Strait, it does not appear to contribute to the extensive pool of cold water that persists through the summer over large areas of the shelf south and southwest of St. Lawrence, the so-called cold spot first described by Barnes and Thompson [1938] and discussed at length by Coachman et al. [1975]. First, the generally northward or eastward flow south of St. Lawrence will not deliver cold polynya waters southward. Second, the polynya is separated from the cold pool of the Bering shelf by warmer waters being advected eastward from the Gulf of Anadyr. Our conclusion in this regard is in fact consistent with Coachman et al. [1975], who argue that the cold pool is maintained by local winter heat loss.

[61] The role of the St. Lawrence polynya in the production of saline water exported northward through Bering Strait can be estimated as follows. The long-term mean January-April transport through the strait is $0.6 \mathrm{~Sv}$, with an incremental winter salinity increase of 0.4 [Woodgate et al., 2005a, Table 1], identical to what we observed in the area bounded by our moored array (Figure 12). The Bering Strait winter salinity increase requires an excess salt flux through Bering Strait of $2.5 \times 10^{5} \mathrm{~kg} / \mathrm{s}$. The corresponding excess salt flux averaged over the area of our moored array is about $5 \%$ of this $\left(0.4 \mathrm{gm} \mathrm{kg}^{-1} \times 6500 \mathrm{~km}^{2} \times 50 \mathrm{~m} / 4\right.$ months $)$. Alternatively, if we consider the undiluted (by advection) effect of ice growth alone $(1.6 \mathrm{~m}$ over the winter, corresponding to a salinity increase of 0.8 (compare section 3.4)), i.e., with no advective freshening tendency, then freezing within the polynya would yield a surface salt flux twice as large. This is still only $10 \%$ of the Bering Strait winter excess salt flux, though, so that the net contribution of freezing within the St. Lawrence polynya to the larger regional salt budget appears to be of second order.

[62] Cumulatively, polynyas are likely important to the regional salt budget. The south coast of St. Lawrence Island approaches $150 \mathrm{~km}$ in length, while other southward facing coast lines in the northern Bering Sea (principally in the Gulf of Anadyr and Norton Sound) total $\sim 700 \mathrm{~km}$. If the polynyas along these other coasts contribute proportionally, we would expect total salt production within the coastal polynyas of the Bering Sea to account for about one-fourth to one-half of the excess winter salinity in Bering Strait. This is consonant with the original suggestion of Aagaard et al. [1981] that in total the polynyas of the northern Bering Sea contribute significantly to the production of dense water, and thereby to the ventilation of the Arctic Ocean halocline.

[63] Regarding the partitioning of the northward flow over the shelf, recall that the nominally eastward alongshore flow south of St. Lawrence decreased markedly from fall to winter, coincident with the increased offshore salinity gradient accompanying polynya formation. An estimate of the 
ensuing seasonal transport change may be made as follows. Assume the applicable section length to extend from P1 (and P2) to a point halfway between F8 (and F5) and H3 (and H4), a distance of about $55 \mathrm{~km}$; the mean section depth to be $47 \mathrm{~m}$; and the seasonal velocity change to be the mean observed at F6 and at F3 and F4, or about $6 \mathrm{~cm} \mathrm{~s}^{-1}$. The corresponding seasonal southeastward transport decrease is then $0.16 \mathrm{~Sv}$, which is about $20 \%$ of the annual mean flow through Bering Strait, and a slightly greater fraction of the mean fall and winter flow through the strait [Roach et al., 1995; Woodgate et al., 2005a]. We do not know with any certainty the extent to which these changes south of St. Lawrence represent a redirecting of the generally northward shelf flow (such that a larger fraction passes through Anadyr Strait instead of through Shpanberg Strait), rather than primarily reflecting the net winter decrease in the Bering Strait throughflow, with a reduced flow through both Anadyr and Shpanberg straits (the mean speed at mooring A3 in Bering Strait dropped about 35\% during the corresponding fall to winter period in 1998-1999). As noted earlier, however, the winter decrease in net flow south of St. Lawrence was larger at the eastern $F$ moorings than at the western ones. This would be consonant with the net northward flow through Shpanberg Strait decreasing in importance in winter.

\subsection{Future Work}

[64] We see clear indications that the region south of St. Lawrence is important in the large-scale exchange of saline water upwelled onto the shelf from the deep Bering Sea with nearshore waters freshened by runoff along the Bering Sea coast. Following Coachman et al. [1975] we suggest that this exchange is critical to the formation of BSW over the midshelf region between St. Matthew and St. Lawrence islands. The BSW is subsequently transported northward through Bering Strait and into the Arctic Ocean, where it contributes importantly to the stratification and nutrient inventory of that basin. On average, the transport of water across the northeastern Bering Sea shelf-break, and thence northward across the shelf, appears mediated by the Bering Slope Current and the topographic beta effect [Kinder et al., 1986]. The wind likely exerts significant control over variations in this transport and in its salt and nutrient load, which depend upon the depth along the slope from which the water is upwelled. Our drifter measurements suggest that the offshore spreading of fresh coastal waters is a fallwinter response to upwelling (northerly) winds. If this is the case, then the offshore spreading of nearshore waters onto the central shelf might be predictable from relatively simple measurements [Lentz, 2004]. On the other hand, Mekoryuk village elders state that there is a northwestward flow of coastal waters along the south coast of Nunivak Island both in summer and fall (L. King, personal communication, 2002), and this flow would of course deflect low-salinity coastal waters toward the central shelf. Such cross-shelf exchanges are likely important to the regional biological production, since they affect stratification over the central shelf and they provide advective pathways for both basin and inner-shelf organisms and nutrients. Indeed, the mixing over the shelf south of St. Lawrence of nitrate- and silicaterich upwelled waters from the deep basin with iron-rich coastal waters might support biological communities and production patterns that differ from those on the southeast Bering shelf.

[65] Takenouti and Ohtani [1974, Figure 2.9b] show that interannual variability in bottom salinities between St. Lawrence and St. Matthew is much greater than the variability in the southeastern Bering Sea. We suspect that this reflects regional differences in cross-shelf exchange mechanisms, but certainly these processes and their temporal and spatial variability have not been addressed for at least the St. Lawrence-St. Matthew portion of the shelf. In their concluding comment, Coachman et al. [1975] state that the oceanography of the Bering Sea shelf between St. Lawrence and St. Matthew islands is unknown. That statement remains as true today as it was 30 years ago.

[66] Our test of the theoretical predictions of the Gawarkiewicz and Chapman [1995] model is incomplete, for while our measurements do not show a cross-isobath eddy density flux or elevated winter eddy kinetic energy levels as predicted, neither do they clearly refute the theory. A distinct possibility is that the dense water was advected downstream of our array before appreciable eddy fluxes materialized. A modest test of this hypothesis would be to employ high-resolution satellite imagery to track the displacement of ice floes in a larger region around St. Lawrence Island. The theory predicts surface eddy velocities of $\sim 20 \mathrm{~cm} \mathrm{~s}^{-1}$, sufficiently strong to discern within the ice drift.

[67] Finally, future idealized process model studies should address the effects of a time-varying alongshore current, with and without horizontal shear, as well as the effects of overlapping surface and bottom boundary layers on the equilibrium timescale and on eddy generation. A regional modeling approach could also shed new light on our results and help guide future observational efforts. Essential elements would include a high-resolution, threedimensional, eddy-resolving model with realistic bathymetry and topography along with properly resolved atmospheric forcing and tides.

[68] Acknowledgments. This paper is dedicated to the memory of Dave Chapman, whose seminal ideas motivated our undertaking. We miss his insights, always offered generously and with a smile. We thank Jens Meincke, without whom the field effort would not have yielded nearly as comprehensive a data set. We have depended especially on the field skills of J. Johnson, D. Leech, A. Welsch, and U. Druebbisch and of Captain W. Rook of the R/V Alpha Helix. J. Smithhisler helped us fabricate the UAF moorings. R. Drucker kindly contributed to several of the figures and underlying calculations. Data cleanup and reduction was aided by S. Sweet. Drifter deployments and associated logistics were carried out by L. King of Mekoryuk, Nunivak Island, and we greatly appreciate his efforts and partnership. We also thank the residents of the village of Gambell who assisted us on a number of instances during both the deployment and recovery field campaigns. Comments by the two anonymous reviewers led to a notable refinement of our presentation. This work was supported by National Science Foundation grant OCE9730697 to the University of Alaska and grant OCE9730823 to the University of Washington. S.M. acknowledges the support of the National Science Foundation under OCE9811097 and of NASA under grant NNG04GM69G. Daily averaged $\mathrm{SSM} / \mathrm{I}$ data used in the ice edge contouring were obtained from the National Snow and Ice Data Center in Boulder, Colorado. The University of Hamburg contributions were funded by the Bundesminister für Bildung und Wissenschaft. Funding for the drifter deployment was made possible by the North Pacific Research Board, grant NPMRI T2130. Manuscript preparation was additionally supported by Office of Naval Research grants N00014-99-1-0345 and N00014-02-1-0305 to the University of Washington. Finally, for those readers who have not seen enough, there are data animations and other related graphics available online at http://www.ims. uaf.edu/SLIP/index.html. 


\section{References}

Aagaard, K., L. K. Coachman, and E. C. Carmack (1981), On the halocline of the Arctic Ocean, Deep Sea Res., 28, 529-545.

Aagaard, K., A. T. Roach, and J. D. Schumacher (1985a), On the winddriven variability of the flow through Bering Strait, J. Geophys. Res., 90, $7213-7221$

Aagaard, K., J. H. Swift, and E. C. Carmack (1985b), Thermohaline circulation in the Arctic Mediterranean seas, J. Geophys. Res., 90, 48334846.

Aagaard, K., C. H. Pease, A. T. Roach, and S. A. Salo (1989), Beaufort Sea Mesoscale Circulation Study-Final report, NOAA Tech. Memo. ERL PMEL-90, Pac. Mar. Environ. Lab., Seattle, Wash.

Amos, A. F., and L. K. Coachman (1992), Water mass modification from the Bering into the Chukchi Sea, in Results of the Third Joint US-USSR Bering \& Chukchi Seas Expedition (BERPAC), Summer 1988, edited by P. A. Nagel, pp. 27-35, U.S. Fish and Wildlife Serv., Washington, D. C.

Baines, P. G., and S. Condie (1998), Observations and modelling of Antarctic downslope flows: A review, in Ocean, Ice and Atmosphere: Interactions at the Antarctic Continental Margin, Antarct. Res. Ser., vol. 75, edited by S. S. Jacobs and R. Weiss, pp. 29-49, AGU, Washington, D. C.

Barnes, C. A., and T. G. Thompson (1938), Physical and chemical investigations in Bering Sea and portions of the north Pacific Ocean, Univ. Wash. Publ. Oceanogr., 3, 35-79.

Bond, N. A., J. E. Overland, and P. Turet (1994), Spatial and temporal characteristics of the wind forcing of the Bering Sea, J. Clim., 7, $1119-1130$.

Brower, W. A., Jr., R. G. Baldwin, C. N. Williams Jr., J. L. Wise, and L. D. Leslie (1988), Climate Atlas of the Outer Continental Shelf Waters and Coastal Regions of Alaska, vol. 3, Chukchi-Beaufort Sea, 497 pp., Natl. Clim. Data Cent., Asheville, N. C.

Cavalieri, D. J. (1994), A microwave technique for mapping thin sea ice, J. Geophys. Res., 99, 12,561-12,572.

Chapman, D. C. (1999), Dense water formation beneath a time-dependent coastal polynya, J. Phys. Oceanogr., 29, 807-820.

Chapman, D. C. (2000), The influence of an alongshelf current on the formation and offshore transport of dense water from a coastal polynya, J. Geophys. Res., 105, 24,007-24,019.

Chapman, D. C., and G. Gawarkiewicz (1995), Offshore transport of dense shelf water in the presence of a submarine canyon, J. Geophys. Res., 100, $13,373-13,387$.

Chapman, D. C., and G. Gawarkiewicz (1997), Shallow convection and buoyancy equilibration in an idealized coastal polynya, J. Phys. Oceanogr., 27, 535-566

Coachman, L. K. (1993), On the flow field in the Chirikov Basin, Cont. Shelf Res., 13, 481-508.

Coachman, L. K., and V. V. Shigaev (1992), Northern Bering-Chukchi Sea ecosystem: The physical basis, in Results of the Third Joint US-USSR Bering \& Chukchi Seas Expedition (BERPAC), Summer 1988, edited by P. A. Nagel, pp. 17-27, U.S. Fish and Wildlife Serv., Washington, D. C. Coachman, L. K., K. Aagaard, and R. B. Tripp (1975), Bering Strait: The Regional Physical Oceanography, 172 pp., Univ. of Wash. Press, Seattle.

Danielson, S., and Z. Kowalik (2005), Tidal currents in the St. Lawrence Island region, J. Geophys. Res., 110, C10004, doi:10.1029/ 2004JC002463.

Drucker, R., S. Martin, and R. Moritz (2003), Observations of ice thickness and frazil ice in the St. Lawrence Island polynya from satellite imagery, upward looking sonar, and salinity/temperature moorings, J. Geophys. Res., 108(C5), 3149, doi:10.1029/2001JC001213.

Gawarkiewicz, G. (2000), Effects of ambient stratification and shelfbreak topography on offshore transport of dense water on continental shelves, J. Geophys. Res., 105, 3307-3324.

Gawarkiewicz, G., and D. C. Chapman (1995), A numerical study of dense water formation and transport on a shallow, sloping continental shelf, J. Geophys. Res., 100, 4489-4508.

Gill, A. E. (1973), Circulation and bottom water formation in the Weddell Sea, Deep Sea Res., 20, 111-140.

Killworth, P. D. (1973), A two dimensional model for the formation of Antarctic bottom water, Deep Sea Res., 20, 941-971.

Kinder, T. H., D. C. Chapman, and J. A. Whitehead Jr. (1986), Westward intensification of the mean circulation on the Bering Sea shelf, J. Phys. Oceanogr., 16, 1217-1229.

Lentz, S. (2004), The response of buoyant coastal plumes to upwellingfavorable winds, J. Phys. Oceanogr., 34, 2458-2469.
Maykut, G. (1986), The surface heat and mass balance, in The Geophysics of Sea Ice, NATO ASI Series B, vol. 146, edited by N. Untersteiner, pp. 395-463, Springer, New York.

McDonald, N. R. (1993), Topographic dispersal of bottom water, J. Phys. Oceanogr., 23, 954-969.

Melling, H. (1993), The formation of a haline shelf front in wintertime in an ice-covered arctic sea, Cont. Shelf Res, 13, 1123-1147.

Melling, H., and E. L. Lewis (1982), Shelf drainage flows in the Beaufort Sea and their effect on the Arctic Ocean pycnocline, Deep Sea Res., 29, 967-985.

Muench, R. D., J. D. Schumacher, and S. A. Salo (1988), Winter currents and hydrographic conditions on the northern central Bering Sea shelf, J. Geophys. Res., 93, 516-526.

Ohtani, K. (1969), On the oceanographic structure and the ice formation on the continental shelf in the eastern Bering Sea, Bull. Fac. Fish. Hokkaido Univ., 20, 94-117.

Overland, J. E., and A. T. Roach (1987), Northward flow in the Bering and Chukchi seas, J. Geophys. Res., 92, 7097-7105.

Pease, C. H. (1987), The size of wind-driven coastal polynyas, J. Geophys. Res., 92, 7049-7059.

Pedlosky, J. (1987), Geophysical Fluid Dynamics, 2nd ed., 710 pp., Springer, New York.

Quadfasel, D., B. Rudels, and K. Kurz (1988), Outflow of dense water from a Svalbard fjord into the Fram Strait, Deep Sea Res., 35, 1143-1150.

Roach, A. T., K. Aagaard, C. H. Pease, S. A. Salo, T. Weingartner, V. Pavlov, and M. Kulakov (1995), Direct measurements of transport and water properties through Bering Strait, J. Geophys. Res., 100, $18,443-18,457$

Schauer, U. (1995), The release of brine-enriched water from Storfjord into the Norwegian Sea, J. Geophys. Res., 100, 16,015-16,028.

Schumacher, J. D., and T. H. Kinder (1983), Low-frequency current regimes over the Bering Sea shelf, J. Phys. Oceanogr., 13, 607-623.

Schumacher, J. D., K. Aagaard, C. H. Pease, and R. B. Tripp (1983), Effects of a shelf polynya on flow and water properties in the northern Bering Sea, J. Geophys. Res., 88, 2723-2732.

Smith, S. D., R. D. Muench, and C. H. Pease (1990), Polynyas and leads: An overview of physical processes and environment, J. Geophys. Res., 95, 9461-9479.

Takenouti, A. Y., and K. Ohtani (1974), Currents and water masses in the Bering Sea: A review of Japanese work, in Oceanography of the Bering Sea, Occasional Publ. 2, edited by D. W. Hood and E. J. Kelley, pp. 3957, Inst. of Mar. Sci. Univ. of Alaska, Fairbanks.

Visbeck, M., J. Marshall, and H. Jones (1996), Dynamics of isolated convective regimes in the ocean, J. Phys. Oceanogr., 26, 1721-1734.

Walter, B. A. (1989), A study of the planetary boundary layer over the polynya downwind of St. Lawrence Island in the Bering Sea using aircraft data, Boundary Layer Meteorol., 48, 255-282.

Weingartner, T., K. Aagaard, R. Woodgate, S. Danielson, Y. Sasaki, and D. Cavalieri (2005), Circulation on the North Central Chukchi Sea Shelf, Deep Sea Res., Part II, 52, 3150-3174.

Winsor, P., and G. Björk (2000), Polynya activity in the Arctic Ocean from 1958 to 1997, J. Geophys. Res., 105, 8789-8803.

Woodgate, R. A., K. Aagaard, and T. J. Weingartner (2005a), Monthly temperature, salinity, and transport variability of the Bering Strait through flow, Geophys. Res. Lett., 32, L04601, doi:10.1029/2004GL021880.

Woodgate, R. A., K. Aagaard, and T. Weingartner (2005b), A year in the physical oceanography of the Chukchi Sea: Moored measurements from autumn 1990-91, Deep Sea Res., Part II, 52, 3116-3149.

K. Aagaard, Applied Physics Laboratory, University of Washington, 1013 NE 40th Street, Seattle, WA 98105, USA.

S. Danielson and T. Weingartner, Institute of Marine Science, University of Alaska, Fairbanks, Room 126 O’Neill Building, Fairbanks, AK 99775 7220, USA. (seth@ims.uaf.edu)

G. Gawarkiewicz and P. Winsor, Woods Hole Oceanographic Institution, Woods Hole, MA 02543-1050, USA.

S. Martin, School of Oceanography, University of Washington, Seattle, WA 98105, USA.

D. Quadfasel, Institut für Meereskunde, Universität Hamburg, Bundesstr. 53, D-20146 Hamburg, Germany. 